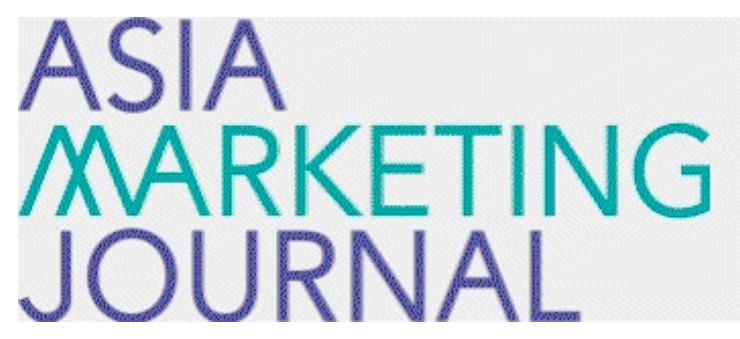

ASIA MARKETING JOURNAL

Volume 4 | Issue 4

Article 1

$12-1-2002$

\title{
CIT를 이푱한 서비스실패와 복구에 관한 연구
}

Sung Wook Yoon

Kyung Mee Hwang

Follow this and additional works at: https://amj.kma.re.kr/journal

Part of the Marketing Commons

\section{Recommended Citation}

Yoon, Sung Wook and Hwang, Kyung Mee (2002) "CIT를 이룡한 서비스실패와 복구에 관한 연구," Asia Marketing Journal: Vol. 4 : Iss. 4 , Article 1.

Available at: https://doi.org/10.53728/2765-6500.1094

This Article is brought to you for free and open access by Asia Marketing Journal. It has been accepted for inclusion in Asia Marketing Journal by an authorized editor of Asia Marketing Journal. 


\title{
CIT를 이용한 서비스실패와 복구에 관한 연구*
}

\section{A Study on Service Failure and Recovery Using CIT}

\author{
윤성욱(동아대학교 경영학부 조교수) \\ weuns@mail.donga.ac.kr
}

황경미(동아대학교 대학원 경영학과 박사과정)

fr3dom@hanmail.net

\begin{abstract}
본 연구는 Critical Incident Technique(CIT)를 이용하여 음식점에서 서비스 실패를 야가 하는 결정적인 사건과 서비스 실패/복구수준과의 관계를 고찰해 보았다. 이와 더볼어 불만 족한 고객을 만족한 고객으로 전환시키는 데에 중요한 역할을 하는 고객이 바라는 복구와 점포 개선사항을 추가로 제시함으로써 실용적인 마케팅 접근을 시도하였다. 본 연구에서는 고객 불만족 원인이 서비스상품의 결함에 대부분 기인한다는 Hof fman et al. (1995)과 Tax et al.(1998)의 결과와는 달리 서비스 실패를 일으키는 주원인은 서비스제공자에게 있다는 홍 미로운 결과를 얻을 수 있었다.

그 동안 국내의 많온 서비스관련 연구들이 서비스 만족과 불만족에 대해 양적 (quantitative)으로 접근한 것과는 달리 본 연구는 질적(qualitative) 접근을 시도하였다. 또한 본 연구는 CIT를 이용한 최초의 서비스 복구에 대한 연구이며, 기존의 연구들이 단순 히 서비스 실패의 유형을 범주화하고 복구의 종류롤 알아보는 것에 그치고 있는 데 반해 본 연구에서는 고객이 바라는 복구종류와 서버스 제공자의 개선 사항, 서비스 실패률 경헙한 고객들의 구전활동에 관한 조사결과와 전략적 시사점도 함께 제시함으로써, 일선 관리자들 이 본 연구의 결과를 기업의 마케팅전략 수립에 효과적으로 활용이 가능하다는 점에서 그 의의가 크다고 할 수 있다.
\end{abstract}

• 논문접수 : 02, 11 게재확정 : 02. 12

** 이 논문은 2002 학년도 동아대학교 학술연구비(공모과제) 지원에 의하여 연구되었음 


\section{1. 문제제기}

오늘날 소비자들은 서비스와 관련된 문제가 발생할 경우 예전보다 휠씬 더 많은 정보를 가지고 이에 대응한다(Brown 1997; Meuter et al. 2000). 따라서 서비스 제공자는 처음부터 서비스 실패가 발생하지 않도록 쳑선을 다하여야 한다. 하지만 어쩔 수 없이 서비스 실패가 발생할 경우 소비자의 불만족을 최소화 시킬 수 있는 복구계힉을 수립하여 고객의 요구에 효율적으로 대웅하여야 한다.

서비스의 독특한 특성으로 인해 고객은 서비스 제공자와 소비자가 상호작용 하는 서비스 접점에서 서비스에 대한 품질지각과 만족/불만족을 인식하게 된다(Bitner 1990; Bitner, Booms and Mohr 1994; Bitner, Booms and Tetreault 1990), 그러므로, 서비스 접점에서 지각 되는 서비스 품질과 고객뷸평 행동에 많은 연구자들의 관심의 초점이 모아졌다(e.g., Parasuraman, Zeithmal and Berry 1985; Jagdip and Wilkes 1996; Tax et al. 1998). 톡히 Keveany(1995)는 서비스 접점에서 서비스 실패로 인해 야기되는 고객의 전한행동에 큰 관심 을 가졌다. 또 다른 학자들은 서비스 실패/복구의 연구에 많은 노력을 기울였다 (e.g., Goodwin and Ross 1992; Kelley et al. 1993; Kelley and Davis 1994; Smith et al. 1999; Weun, Beatty, and Jones (forthcoming)). 여기서 홍미로운 사실은 서비스 접점에서 발생하는 서비 스 실패와 복구에 관한 연구에는 CIT를 이용한 연구가 많이 존재한다는 것이다(e.g., Bitner, Booms and Tetreault 1990; Chung and Hof fman 1998; Dolen et al. 2001; Edvardsson

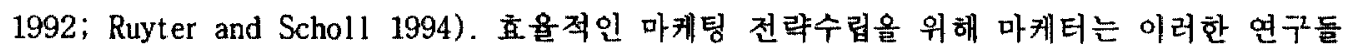
을 바탕으로 서비스 접점에서 발생할 수 있는 만족과 불만족을 야기하는 결정적인 사건 (critical incidents)에 대해 분석하고 이률 개선할 수 있는 방법을 찾아야 한다.

서비스의 중요성에 대한 인식이 높아짐에 따라 국내에서도 서비스 접점과 서비스 실패/복 구에 대한 연구들이 이루어지고 있다. 이러한 연구들은 주로 고객 접점 종업원의 서비스 품 질과 고객만족과의 관계(이용기 2001), 지각된 서비스 품질과 재이용 의도에 대한 관계(이 인구 둥 2000)로 서비스 품질과 만족, 만족후의 결과들에 관련된 연구들이 일반적이다. 그 리고, 소비자 불평행동과 관련하여 고객의 특성, 제품유형, 관련비용과 불평행동의 영햫관 계(이기춘·조희경 1996; 류미현·이숭신 1997)와 소비자 불만족과 대웅행동(이은화 - 민남 희 2000), 서비스실패가 발생한 상황 하에서 관계의 질의 역할(윤성욱 2002)에 대한 연구들 로 단순히 소비자의 불만족과 관련된 대웅행동에 관한 연구들이다. 서비스 실패와 기입의 복구 노력 둥 고객불만에 대한 기업의 대옹에 대한 연구의 필요성을 인식한 장홍섭과 튜갑 경 (2002)에 의해 서비스 실패/복구에 대한 연구가 이루어 겼지만 그들 또한 실패롤 야기하 는 결정적인 사건과 복구는 연구의 고려 대상으로 포함하지 않았다. 더욱이 이상의 연구들 이 모두 양적 조사방법으로 이루어졌기 대문에 일반적인 사항에 대한 고객의 태도를 알아보 는 것은 가능하나 소비자 불만족에 대한 정교한 부분을 알아보기에는 연구방법의 특성상 무 리가 있다.

CIT는 고객만족/불만족, 그리고 서비스 실패와 복구를 연구하는 데 유용한 기법으로써 많 은 해외 연구자들 사이에서 이용되었지만 국내의 마케팅 분야에서는 CIT를 이용한 연구가 거의 전무한 것이 사실이다(e.g., Bitner, Booms and Tetreault 1990; Chung and Hof fman 1998; Dolen et al. 2001; Edvardsson 1992; Ruyter and Scholl 1994). 따라서 본 연구자들은 서비 
스 접점에서 발생하는 서비스 실패/복구에 대해 CIT률 이용하여 고객의 만족/불만족을 분류 하는 수준예서 벗어노 고객이 기업에 원하는 대옹행동을 함께 제시합으로써 마케터들이 서 비스 실패로 불만족한 고객에개 효율적으로 대웅할 수 있는 방안을 재시하고 기업이 서비스 접점을 전략적으로 관리할 수 있도록 기여하는데 본 연구의 목적을 두고 있다.

\section{2. 이론적 고찰}

\section{1 서비스 접점}

서비스는 그 톡성상 고객과 기업 혹은 종업원이 상호 작용하는 과정에서 평가된다 (Bitner 1990; Bitner, Booms and Mohr 1994; Bitner, Booms and Tetreault 1990). 이 상호 작 용하는 동안을 Shostack(1985)은 서비스 접점이라고 하였고, Normann(1983)은 진실의 순간 (moment of truth)이라고 하였다. 서비스 접점에 대한 초기의 정의는 주로 고객만족을 위한 상호작용 측면을 강조하였다(Shostack 1985), Surprenant 와 Solomon(1987)은 인적 상호작용 측면을 강조하여 서비스 접점을 고객과 서비스 제공자의 상호작용으로 정의하였으며, Walker(1995)는 서비스 접점에 대한 보다 명확한 개넘정립을 위하여 서비스 접점에서 만족 을 하게 되는 과정을 소비 전 평가단계, 소비 중 평가단계, 소비 후 평가단계인 3단계로 나 누어 연구하였다. 그는 3단계 모두가 서비스 평가에 영향을 미치므로 관리자는 언제, 어디 서, 어떻계, 왜 서비스를 제공해야 하는가에 주의를 기울여야 한다고 하였다. Lewis와 Entwistle(1990)도 많은 학자들의 연구를 바탕으로 서비스와 서비스 접점의 특징을 다시 한 번 명확히 하기 위해 서비스 접점을 기업과 종업원의 상호작용인 내부접점과 고객과 종업원 과의 상호작용인 외부접점으로 구분하였다. Shostack(1985, p. 243)은 서비스 접점을 “서비 스가 졔공되는 동안 고객이 직접적으로 서비스에 관여하는 때" 라고 하여 좀더 광범위하개 정의하였다. 그녀의 정의를 퉁해불 매 고객은 서비스 기업이 재공하는 인적 요소, 물리적 요소와 더불어 고객에게 영향을 미칠 수 있는 모든 요소들과 상호작용 함을 알 수 있다. 즉, 고객은 눈에 보이는 인적 - 물리적인 요소에 의해서만 영향을 받는 것이 아니라 그 순간 그 상황에 놓여있는 모든 요소돌에 의해 영향을 받는 것이다. 따라서 본 연구에서는 서비스 접 점을 Shostack(1985)의 정의를 근간으로 하여' 서비스 제공자와 서비스 지각에 영향을 미 칠 수 있는 주변의 모든 요소와 고객의 상호작용으로 인하여 고객이 만족과 불만족을 느끼 는 때' 라고 정의하였다.

마케팅관련 연구에서 서비스 접점이라는 용어는 근래에 와서 광범위하게 사용되기 시작하 였다. Bitner 와 그의 동료들은 1990년과 1994에 항공사, 호텔, 음식점을 대상으로 서비스 접점에서 만족과 불만족을 발생시키는 원인들을 고객과 종업원의 입장에서 알아보았다. 이 들의 연구에서는 CIT가 이용되었으며, 서비스 접점에서 불만족한 고객에 대한 분류 시스템 을 통해 종업원들이 적절하게 대옹할 경우 불만족을 만족의 상태로 이끌 수 있으며, 그렇게 하기 위해서 관리자들은 고객접점 중업원의 지식수준에 영향을 줄 수 있어야 하고, 그들의 행동을 통제할 수 있는 능력을 지녀야함을 언급하였다.

Sundaram 과 Webster $(2000)$ 는 서비스 접점에서 종업원의 비언어적인 의사소통 행위도 종 
업원의 신뢰성, 친밀성, 정중함, 공감성, 능력을 평가하는 데 중요한 영향을 미치는 요소로 작용할 것이므로 이에 대한 연구 또한 의미가 있옴을 주장하였다. 예률 들어 눈맞춤, 고개 끄덕임, 미소률 의미하는 신체적인 언어와 목소리의 크기, 강세의 변화률 뜻하는 준 언어, 서비스 제공자와 고객 사이의 거리와 상대적인 자세, 각별한 접촉과 같은 거리/공간 관계, 그리고 마지막으로 서비스 제공자의 외모는 비언어적인 요소로 서비스 접점에서의 서비스 평가에 중대한 영향을 미친다는 것이다. 또한 Price et al.(1995)에 따르면 서비스 접점에서 고객이 만족/불만족 상태에 있을 경우 종업원의 감정반웅은 고객에게 직접적인 영향을 미친 다고 한다. 특히, 고객이 불만족한 상태에 있을 경우 종업원의 부정적인 감정반옹은 고객의 불만족을 더옥 심화 시키는 역할을 하기 때문에 서비스 제공자는 고객에 대한 이해와 곤심 등 높은 수준의 인간적인 배려률 하여야 한다는 것이다. Lewis와 Entwistle(1990)은 서비스 접점을 제대로 관리하기 위해서 종업원들은 서비스 과정과 절차에 관련된 기술, 사람과 관 련된 기술, 상황에 대처할 줄 아는 행동의 유연성, 적웅성, 그리고 서비스률 받은 고잭의 입장을 이해할 수 있는 감정을 가져야 함을 주장하면서 서비스 제공자는 조직내의 관계 개 선과 고객 지향성을 위해 스탭들에 대한 교육뿐만 아니라 종업원의 기술과 지식에 합당한 교육에 지속적인 관심을 가져야함을 강조하였다.

\section{2 만족과 불만족에 관한 연구}

고객은 서비스 접점에서 서비스 품질을 인식하게 되고 서비스에 대한 만족과 불만족을 경 험하개 되므로 서비스 접점에서 발생하는 고객의 만족과 불만족에 영향을 미치는 요인둘과 이들의 영향에 관한 연구가 지속적으로 이루어져 왔다(Bitner, Booms and Tetreault 1990; Shostack 1985; Sundaram and Webster 2000; Walker 1995; Weun et al. forthcoming; 윤성욱 2002). 이유재(2000)는 지금까지 고객만족에 대한 국내 문헌과 외국 문헌들을 중심으로 고 객만족은 크게 볼 때 졀과(outcome)에 의한 것과 과정(process)에 의한 것이 있으며, 만족 은 기대, 불일치에 의해 발생하고, 고객 만족/불만족의 결과변수로 가장 많이 다루어진 변 수는 불평행동과 구전, 재구매 행동 둥이 있음을 지적한 바 있다. 이러한 이유재(2000)의 지적과 유사한 맥락으로 고객만족/불만족에 관련한 국내 문헌들의 연구결과에 비추어볼 때 서비스 접점에서의 종업원의 규정적인 역할과 비 규정적인 역할은 서비스 품질지각에 영향 을 주며 특히, 비 규정적인 역할은 서비스 품질을 높이는 데 긍정적인 영향을 미친다(Price et al.1995; 이용기 2001). 고객이 서비스 품질을 높게 인식할수록 만족 또한 높아지며 만 족한 고객은 기업에 대한 애호도를 가지고 호의적인 구전행동을 하는 등 기업에 적극적인 참여와 협조를 하게 된다(이용기 2001). 이수형 둥(2001)은 신뢰와 만족은 장기적인 관계형 성 유지에 매개 역할을 하며, 특히 이인구 둥(2000)은 인적 서비스 차원인 종업원의 친철은 고객이 서비스 품질울 높게 지각하는 데 영향을 미칠 뿐만 아니라 소매점에 대한 태도와 재 이용 의도에도 영향을 미친다고 하였다.

고객 불만족과 관련한 연구들에 의하면 의료서비스는 의료서비스 만이 가지는 독특한 특 성 때문에 환자가 불만족을 경혐하더라도 뼐다론 불만호소행동을 취하지 않으며, 불만족하 였음에도 불구하고 재 구매 의도를 가진다(이기춘·조희경 1996). 그러므로 의료서비스 부 분에서는 서비스의 질을 높이기 위한 고객 지향적인 마케팅활동이 등한시되어 왔다고 불 수 있다. 하지만 가전제품의 경우 고객이 불만족을 경헙하게 되면 기업에 대해 사적인 행동 또 는 공적인 행동을 취하게 되는데 이는 고객의 특성, 게품유형, 관련비용과 관련을 가진다 
(류미현-이승신 1997), 또한 고객이 불만족에 대한 대웅행동에 자신감이 높을수록 대응행 동 수준이 높고 그 반대의 경우는 대웅행동 수준이 낮게 나타난다(이은희 - 민남희 2000).

지금껏 한국의 많은 고객 만족/불만족에 대한 연구들은 단순히 소비자의 불만족의 대웅햄 동인 불평올 주요한 결과변수로 다루고 있다. 이러한 한계점을 극복하기 위해 장홍섭과 튜 갑경 (2002)은 원인변수로서의 고객 불평행동에 대한 기업의 대응 변수률 고려하여 고객이 불만족하였을 때 기업이 고객의 불평을 처리함으로써 불만족한 고객을 만족하는 고객으코 전환시킬 수 있으며, 불평처리 후 만족이 높을수록 소비자의 기업몰입의 정도와 재 구매 의 도가 높아짐을 보여주었다.

소비자 만족/불만족과 퐌련한 국내의 많은 연구 중 일부인 위의 연구 결과들과 서비스 실 패에 관련한 연구들을 연구의 대상 분야와 내용, 그리고 결과를 중심으로 요약해 보면 아래 의 <표 1>과 같다. <표 1>을 통해 볼 때 기존의 국내에서 아루어진 고객 만족/불만족에 관 한 연구들은 연구자 중심적이며, 결과변수에만 관심을 가지고 있음을 알 수 있다. 그리고, 고객이 불만족 하였을 경우 고객 대옹행동과 고객 불평에 대한 기업 대웅행동이 연구의 관 심으로 부상하고 있기는 하지만 이와 관련된 대부분의 연구들 또한 양적인 연구로 고객의 입장을 제대로 반영하는 것이 곤란하다는 한계를 지닌다. 
<표 1> 고객 만족/ 불만족과 서비스 실패에 관련한 선행연구

\begin{tabular}{|c|c|c|c|c|}
\hline 연구자 & 수 & $\begin{array}{l}\text { 대상 } \\
\text { 분야 }\end{array}$ & $\begin{array}{l}\text { 분석 } \\
\text { 방법 }\end{array}$ & 연 구 내 용 및 결 과 \\
\hline $\begin{array}{c}\text { 류미현 } \\
\text { • } \\
\text { 이숭신 } \\
\text { (1997) }\end{array}$ & $\begin{array}{l}\text { 소비자문제 } \\
\text { 경혐/ } \\
\text { 소비자 } \\
\text { 불만족/ } \\
\text { 소비자 대웅 } \\
\text { 행동 }\end{array}$ & $\begin{array}{l}\text { 가전 } \\
\text { 제품을 } \\
\text { 사용 } \\
\text { 하는 } \\
\text { 주부 }\end{array}$ & $\begin{array}{l}\text { 중화과 } \\
\text { 분석 } \\
\text {. } \\
\text { 경로 } \\
\text { 분석 }\end{array}$ & $\begin{array}{l}\Delta \text { 소비자 문제경혐온 품질문제, 애프터서비스 순으 } \\
\text { 로 나타남. } \\
\Delta \text { 소비자 불만족의 순위는 품질불만족, 가격밚만족, } \\
\text { 광고 불만족, 애프터 서비스 불만족 순으로 나타 } \\
\text { 남. } \\
\Delta \text { 소비자 문제경험과 불만족에 대한 대웅행동은 무 } \\
\text { 행동, 사적과 공적행동, 공적행동, 사적행덯 순으 } \\
\text { 로 나타남. } \\
\Delta \text { 소비자 문제경헙이 많을수록 대웅행동을 많이 하 } \\
\text { 게됨. }\end{array}$ \\
\hline $\begin{array}{l}\text { 윤성욱 } \\
\text { (2002) }\end{array}$ & $\begin{array}{c}\text { 관계의질/ } \\
\text { 귀인/서비스 } \\
\text { 복구기대/ } \\
\text { 구전 }\end{array}$ & $\begin{array}{l}\text { 대학 } \\
\text { 교육 } \\
\text { 서비스 }\end{array}$ & $\begin{array}{l}\text { 공변량 } \\
\text { 구조 } \\
\text { 방정식 }\end{array}$ & $\begin{array}{l}\Delta \text { 서비스 실패의 경우, 서비스 제공자와 고객간의 } \\
\text { 관계의 질은 관계강화 귀인에 유의한 영항:을 미 } \\
\text { 침. } \\
\text { 관계강화 귀인은 고객의 서비스복구에 대한: 기대 } \\
\text { 에 유의한 영향을 미침. }\end{array}$ \\
\hline $\begin{array}{c}\text { 이기춘 } \\
\cdot \\
\text { 조회경 } \\
\text { (1996) }\end{array}$ & $\begin{array}{l}\text { 진료시간/ } \\
\text { 시간비용/ } \\
\text { 소비자불만족 } \\
\text { /불만호소행 } \\
\text { 동/재구매 }\end{array}$ & $\begin{array}{l}\text { 의 료 } \\
\text { 서비스 }\end{array}$ & $\begin{array}{l}\text { 분산 } \\
\text { 분석 } \\
\text { 중회귀 } \\
\text { 분석 }\end{array}$ & $\begin{array}{l}\Delta \text { 의료 서비스에 대해 소비자돌은 대부분 불만족함. } \\
\Delta \text { 시간비용 서비스에 대한 불만족이 가장 높음 } \\
\Delta \text { 불만족은 재 구매 의도에 영향을 미치지 못함. }\end{array}$ \\
\hline $\begin{array}{l}\text { 이수형 } \\
\quad \text { 등 } \\
(2001)\end{array}$ & $\begin{array}{c}\text { 판매원의 접 } \\
\text { 촉강도/상호 } \\
\text { 솔직합/협력 } \\
\text { 의도/유사성/ } \\
\text { 전문성/신뢰/ } \\
\text { 만족/미래상 } \\
\text { 호작용 }\end{array}$ & 백화점 & $\begin{array}{l}\text { 공변량 } \\
\text { 구조 } \\
\text { 방정식 }\end{array}$ & $\begin{array}{l}\Delta \text { 판매원의 접촉강도와 상호 솔직함은 신뢰에 영향 } \\
\text { 을 미치지 않음. } \\
\Delta \text { 판매원의 접촉강도와 상호 솔직함은 고객의 만족 } \\
\text { 에 영향을 미치지 않음. } \\
\Delta \text { 유사성은 만족에 영향을 미치지 않음. } \\
\Delta \text { 판매원의 전문성은 만족과 신뢰에 영향을 미침. } \\
\Delta \text { 판매원의 협력 의도는 신뢰와 만족에 영힝을 미 } \\
\text { 침. } \\
\Delta \text { 판매원의 유사성은 신뢰에 영향을 미침. } \\
\Delta \text { 신뢰와 만족은 미래 상호작용에 영향을 미침. }\end{array}$ \\
\hline
\end{tabular}




\begin{tabular}{|c|c|c|c|c|}
\hline 연구자 & 변 수 & $\begin{array}{l}\text { 대상 } \\
\text { 분야 }\end{array}$ & $\begin{array}{l}\text { 분석 } \\
\text { 방법 }\end{array}$ & 연 구 내 용 및 \\
\hline $\begin{array}{l}\text { 이용기 } \\
(2001)\end{array}$ & $\begin{array}{l}\text { 서비스품질/고 } \\
\text { 객만족/애호도 } \\
\text { /협조/참여/비 } \\
\text { 규정 역할/규 } \\
\quad \text { 정역할 }\end{array}$ & 음식점 & $\begin{array}{c}\text { 공변량 } \\
\text { 구조 } \\
\text { 방정식 }\end{array}$ & $\begin{array}{l}\Delta \text { 규정역할은 서비스 품질을 높이는 데 영향을 미 } \\
\quad \text { 침. } \\
\Delta \text { 비 규정역할은 서비스 품질올 높이는 데 형향을 } \\
\quad \text { 미침. } \\
\Delta \text { 서비스 품질이 높으면 고객만족 또한 높아짐. } \\
\Delta \text { 고객만족은 애호도와 참여, 협조에 영향을 미침. }\end{array}$ \\
\hline $\begin{array}{l}\text { 이은화 } \\
\text { · } \\
\text { 민남희 } \\
(2000)\end{array}$ & $\begin{array}{l}\text { 대응행동 설명 } \\
\text { 변수/소비자 } \\
\text { 불만족/불만족 } \\
\text { 에 대한 소비 } \\
\text { 자 } \\
\text { 대융행동 }\end{array}$ & $\begin{array}{l}\text { 학 원 } \\
\text { 교 육 } \\
\text { 서비스 }\end{array}$ & $\begin{array}{c}\text { T-test } \\
\cdot \\
\text { 분 산 } \\
\text { 분 석 }\end{array}$ & $\begin{array}{l}\Delta \text { 학원시설, 수강생 수에 따라 불만족에는 차이가 } \\
\text { 있음. } \\
\Delta \text { 학원비와 대응행동 간에는 정적인 관계가 있옴. } \\
\Delta \text { 대응행동에 대한 이익 인식도가 높은 집단딜수록 } \\
\text { 대응행동에 적극적임. } \\
\Delta \text { 대응행동에 금전적인 비용, 시간, 노력, 십리적 } \\
\text { 부담감이 영향을 미침. }\end{array}$ \\
\hline $\begin{array}{c}\text { 이인구 } \\
\text { 둥 } \\
(2000)\end{array}$ & $\begin{array}{c}\text { 인적서비스/ } \\
\text { 비 인적서비스 } \\
\text { /소매점에 } \\
\text { 대한 태도/ } \\
\text { 재이용의도 }\end{array}$ & $\begin{array}{c}\text { 할인점, } \\
\text { 백화점, } \\
\text { 재래시장 } \\
\text { 둥의 소 } \\
\text { 매점 }\end{array}$ & $\begin{array}{c}\text { 공변량 } \\
\text { 구조 } \\
\text { 방정식 }\end{array}$ & $\begin{array}{l}\triangle \text { 인적서비스 차원인 신뢰는 소매점에 대한 태도에 } \\
\text { 영향을 미침. } \\
\Delta \text { 인적 서비스 차원인 친절은 소매점에 대한 태도에 } \\
\text { 영향을 주지 못함. } \\
\Delta \text { 비 인적 서비스인 시설은 소매점에 대한 태도에 } \\
\text { 영향올 미침. } \\
\Delta \text { 비 인적 서비스인 가격은 소매점에 대한 태도에 } \\
\text { 부정적인 영향올 미침. } \\
\Delta \text { 소매점에 대한 태도는 재 구매의도에 영향을 미 } \\
\text { 침. }\end{array}$ \\
\hline $\begin{array}{c}\text { 장홍섭 } \\
\text { · } \\
\text { 류갑경 } \\
(2002)\end{array}$ & $\begin{array}{c}\text { 기업반웅/불평 } \\
\text { 후 객만족/불 } \\
\text { 평처리 후 } \\
\text { 소비자 반웅 }\end{array}$ & 일 반인 & $\begin{array}{ll}\text { 회 귀 } \\
\text { 분 석 }\end{array}$ & $\begin{array}{l}\Delta \text { 기업반응은 불평처리 후 고객의 만족에 영향을 미 } \\
\text { 침. } \\
\Delta \text { 불평처리 후 만족이 높을수록 소비자의 기업몰입 } \\
\text { 의 정도는 높아짐. } \\
\Delta \text { 불평처리 후 만족이 높을수록 재 구매의도는 높아 } \\
\text { 짐. }\end{array}$ \\
\hline
\end{tabular}

\section{3 서비스 실패와 복구}

서비스의 특성상 서비스 제공자는 제공되는 서비스의 모든 상황을 통제할 수 없을 뿐단 아니라, 서비스품질에 영향을 미치는 많은 요소들에 대한 통재도 불가능하므로 동일한 서비 스라 할지라도 고객이 느끼는 서비스의 품질은 다를 수 있다(Bejou et al. 1996). Parasuraman et al. (1991, p42)은 " 고객은 서비스에 대해 그들 나름대로의 특정한 기대수촌 을 가지고 있으며, 이것이 서비스률 적정 서비스와 기대 서비스로 구분하게 한다. 그리고, 
개인의 옥구와 받아들이는 서비스 수준을 허용영역(zone of tolerance)이라고 하며, 이 허용 영역은 아코디언처럼 늘어나기도 하고 줄어들기도 하기 때문에 각 개인에 따라 허용영역은 다르며, 동일한 고객에 있어서도 상항에 따라 달라질 수 있다." 라고 하였다. 이률 KelHey 와 Davis(1994)의 기대-불일치 패러다임에 적용해 본다면 기대 수준이 허용영역 이하로 떨 어지게 되면 고객은 서비스 실패를 지각하게 되고, 서비스 실패는 사소한 것에서부터 싣각 한 것에 이르기까지 다양하게 나타난다. 따라서 고객이 느끼는 서비스 실패에 대한 대용방 법 또한 여러 가지가 될 수 있고 대웅 방법에 따라 고객이 느끼는 복구정도 또한 다률 짓임 을 알 수 있다.

고객들온 서비스 실패가 발생하게 되면 서비스 복구를 기대할 뿐만 아니라 적정한 수준의 복구를 기대하고 요구하게 된다(Bitner et al. 1990; Smith and Bolton 1998; Tax et al. 1998; Weun et al. forthcoming; 윤성욱 2002), 또한 서비스 실패의 경우 서비스 제공자나 고객간 의 관계의 질은 그돌의 관계강화 귀인에 영향을 주며, 관계강화 귀인은 고객의 서비스 복구 에 대한 기대에 영향을 주므로 서비스 제공자는 고객의 기대수준에 합당한 서비스 복구를 해 주어야 한다(윤성욱 2002).

서비스 실패가 발생하였을 때 종업원의 긍정적인 대웅과 적절한 불평처리는 불만족한 포객 을 만족한 고객으로 전환시킬 뿐만 아니라 전환된 만족은 기업에 대한 신뢰와 믈입에 영향 을 미친다(Bitner et al. 1990, 1994; Johnston 1995; Tax et al. 1998). 또한 “ 효과적도로 서비스 실패률 관리할 경우 우호적인 고객 행동으로 연결되어 고객의 서비스 복구를 가져올 뿐만 아니라 신규고객 창출을 가능하게 한다." (Swanson and Kelley 2001, p.195). 고객의 불 평에 공감하면서 취하는 상황예 따른 신속하고 유연성 있는 대웅은 불만족한 고객을 만족한 고객으로 전한시키는 데 결정적인 역할을 하며, 고객유지, 고객만족, 서비스 조직에 대한 애호의도, 호의적인 구전에 중요한 역할을 한다(Johnston 1995). 이와는 반대로 서비스 제 공자가 서비스 복구에 실페하게 되면 고객은 다른 경쟁기업으로 전환을 하거나 부정적인 구 전행동을 취하게 되므로 기업은 장기적으로 불 때 이익이 감소하게 되는 불이익을 겨게 된 다(Smith et al. 1998). Keaveney(1995)는 서비스 실패에 대한 대웅이 좋지 않을 경우 고객 들은 자신이 경혐한 상황을 단지 서비스 실패의 경협으로만 생각하는 것이 아니라 그들 중 $17 \%$ 는 다른 경쟁사로 옮겨가는 행동을 취한다고 하였다. 그러므로, 호과적인 서비스 복구에 대한 중요성에 많은 학자의 관심이 모아지고 있다(e.g., Bitner et al. 1990, 1994; Brown 1997; Keaveney 1995; Smith et al. 1999; Tax et al. 1998; Weun et al. forthcoming).

Hof fman et al. (1995)은 음식점을 대상으로 그코에서 발생하는 서비스 실패의 종류와 복구 의 유형을 분류하고, 복구유형 중 고객들의 불만족을 만족으로 전환시키는 데 가장 크게 작 용하는 것이 무엇인가를 알아보았다. Goodwin 과 Ross(1992)는 소비자들은 사과를 받거나 자신들의 관심사를 표현할 수 있는 기회가 주어졌을 때, 특히 서비스 실패 복구를 위해 제 공된 복구유형이 적합할 때 만족이나 공정성에 관한 지각이 높아진다고 하였다.

고객이 불만족을 하게 되는 이유돌 중 가장 중요한 원인온 서비스 실패에 대한 서비스 제 공자 측의 반웅 결여이며 불만족의 $43 \%$ 가 무례한 종업원으로 인해 발생한다(Bitner et al. 1990). 하지만 위에서도 언굽 되었듯이 종업원의 고객 욕구에 부웅하는 적절한 대옹은 서비 스 접점에서의 실패로 인해 불만족한 고객을 만족한 고객으로 전환시킬 수 있다. 그러기 위 해서는 서비스 실패로 인해 불만족한 고객에게 문제발생에 대한 정보를 제공할 수 있어야 하고, 문제를 어떻게 처리할 것인 지의 여부와 고객의 요구들 중 받아들여질 수 있는 부분 은 무엇이며, 그렇지 않은 부분은 무엇인가에 대한 설명과 그에 대한 적졀한 이유 또한 제 
공 되어져야 한다(Bitner et al. 1990). 예나하면 서비스 복구는 서비스 실패를 격은 고객에 게 그들의 기대와 요구에 합당한 보상을 해줌으로써 그들을 고정고객으로 만들 수 있게 하 는 기회를 제공해줄 뿐만 아니라 신규고객을 창출할 수 있는 기회를 제공해 주기 때문이다 (Brown 1997; Tax et al. 1998; Weun et al forthcoming). 그러므로 본 연구에서도 서비스 실 패를 격은 고객올 만족한 고객으로 전한시키기 위해 어떠한 복구가 좀 더 고객 지향적이면 서 서비스 제공자에게 효율적인가를 고찰해 보고자 한다.

\section{3. 연구방법}

\subsection{CIT와 연구절차}

서비스 접점에서 발생하는 불만족과 이에 대한 대웅방법을 알아보기 위해 본 연구는 질: 적 연구방법들 중의 하나로 많은 학자들에 의해 선호되어온 CIT(Critical Incident. Technique)를 이용하였다(e.g., Bitner, Booms and Tetreault 1990; Chung and Hof fman 1998; Dolen et al. 2001; Edvardsson 1992; Hoffman, Kelley and Rotalsky 1995; Johnston 1995; Meuter et al. 2000; Stauss 1993). Edvardsson(1992)에 따르면 CIT란 Flauagan에 의해 1954 년 Psychological Bulletin에 처음 소개되었으며, 서비스 실패가 발생한 곳을 눱게 알 수 있도록 해 주는 질적 연구방법이다. 또한 서비스 이용 시 경험한 만족이나 불만족을 고객의 인터뷰를 통하거나 직접 기록하는 방법을 취하기 때문에 만족이나 불만족을 발생시키는 곌 정적인 사건에 대한 상세한 내용을 알 수 있게 해줌으로 서비스 품질의 결함을 분석하고 까 정하는 데 있어 유용하고 적절한 방법으로 증명되었다. 또한, 서비스 제공자는 불만족을 깅 험한 고객의 체험내용을 분석함으로써 불만족의 유형을 파악하게 되고 다른 고객들이 불핑 하기 전에 부족한 품질을 개선할 수 있게 됨으로 고객의 불평에 대한 대응이 용이하다. $\mathrm{CI}$ ? 롤 이용하면 이미 발생한 결점들을 근거로 하여 다른 결점들을 보완하고 고객들을 보살필 수 있게 되며, 명확하고 신속하며 믿울 수 있는 정보 뿐만 아니라 일반화된 보상을 제공할 수 있는 정보도 얻을 수 있다. Meuter et a].(2000)에 따르면 질적 방법으로서의 CIT는 조시. 를 통해 현상을 일반화하는 것이 아니라 현상의 본질을 볼 수 있는 통찰력을 제공하며, 특 히 고객에게 만족과 불만족을 줄 수 있는 여러 종류의 다양한 결정적인 사건들을 몇 개의 큰 범주로 구분할 수 있게 하고, 수량적으로 연결하기에는 부적합한 특정 사건들을 각각의 하부 사건들로 구분하여 고객의 언어로 해석을 조합할 수 있게 함으로서 서비스 관리자들어 게 서비스품질을 개선시킬 수 있는 방법에 대한 정보를 제공하는 독특한 기법이다. 이처럽 CIT가 지니는 장점으로 인해 서비스 실패와 복구에 관련된 해외의 많은 연구듈이 CIT를 이 용하여 질적자료(qualitative data)률 분석하였지만, 국내에서는 본 연구가 CIT를 이용한. 최초의 서비스 복구에 관한 연구라 할 수 있다.

본 연구에서 고객 불만족의 원인이 된 결정적인 사건과 서비스 제공자의 대응행동인 복 구유형으로 분류하는 과정은 Hof fman et al. (1995)이 이용한 방법을 근간으로 하여 (1) 연구 목적 결정 (2) CIT를 이용한 자료 수집계획 수립 (3) 조사자 교육 (4) 자료 수집 (5) 자료. 분석 (6) 자료의 해석이라는 여섯 단계로 이루어겼다. 수집된 자료의 분석과 자료의 해석부 
분에서는 자료의 해석상 발생할 수 있는 오류롤 방지하고 조사자간 신뢰성을 높이기 위해 여러 번의 중복작업이 이루어졌다.

\section{2 자료수집}

자료 수집을 위해 연구자들은 부산지역에 거주하는 대학생들에게 본 연구의 중요성과 설 문작성 방법을 교욕한 후 서비스 접촉이 빈번하게 발생하는 음식점에서 격은 본인과 타인이 서비스 실패경헙을 설문지에 직접 기록하게 하였다. 또한 자료의 질을 높이기 위해 타인 설 문지의 경우 학생이 임의로 작성함으로쌔 발생할 수 있는 오류를 없애기 위해 전화번호를 기재하게 한 후 무작위로 선택된 전화번호를 통해 본인이 직접 설문에 웅답한 것인가의 여 부를 확인하였다. 수집된 자료에 대한 범주화 과정에서 부적절한 자료를 제외하고 촣 515 개 의 자료가 본 연구를 위해 사용되었다. 수집된 자료들은 패스트푸드점과 관련한 자료 30 개 와 무 응답 3 개를 제외하면 모두 일반 음식점과 관련된 것이다. 음식점 유형과 응답자의 일 반적인 톡성은 여성263(51.1\%), 남성 249(48.3\%)이었으며, 학력은 고졸이하 99 (19.2\%), 대 재 $269(52.2 \%)$, 대졸 $127(24.7 \%)$, 대학원졸 $17(3.3 \%)$ 로 나타났다. 연령은 20 대가 332 명 $(64.5 \%), 30$ 대 70 명 (13.6\%), 40대 71 명 $(13.8 \%), 50$ 대 이상 42 명(3.2\%)으로 집계되었다.

본 연구에 이용된 질문은 Hoffman 과 Bateson(1997)의 설문형식을 본 연구의 목적에 부 합되도록 일부 수정햐여 사용하였으며, 질문내용은 음식점에서 경헙한 불만족과 관련된 것 으로 축소하였다. 설문지는 (1) 음식점에서 격은 좋지 않은 서비스 경헙의 내용, (2) 서비 스 경험의 심각성 정도, (3) 고객의 불만족에 대한 점포 측의 반웅, (4) 점포 측의 대웅정도, (5) 점포 측의 대웅 시 응답자가 느꼈던 아쉬운 점, (6) 점포에서 해 주었으면 하고 바랬던 복구내용, (7) 불만족한 이후 점포의 계속 이용여부, (8) 만약 그 점포를 계속 이용한마면 계속 이용하는 이유, (9) 점포에 대해 아쉬욌거나 개선해 주었으면 하고 바라는 점, (10) 그 점포에 대해 다른 사람들에게 권유하고 싶은 가의 여부, (11) 평소 쟈신의 경헙을 다른 사 랍에게 구전하는지의 여부와 (12) 만약 구전을 한다면 좋았던 일과 나쌌던 일 중 어떤 쪽을 더 많이 하는가를 물어보는 항목, 그리고 (13) 간단한 인구 통계적인 부분을 물어보는 항목 으로 구성되었다. 설문에 이용된 척도로는, 서비스 경헙의 심각성 정도와 점포의 서비스 실 패에 대한 복구정도를 알아보기 위한 점포 측의 대웅 정도를 묻는 항목에 대해서는 각각 점 포의 실수 정도가 사소한 실수일 경우 1, 심각한 실수일 경우 10 을, 대응정도가 아주 나빴 을 경우 1 , 아주 좋았을 경우 10 을 선택하는 10 점 척도를 이용하고, 나머지 항목에 대해서 는 명목척도와 웅답자가 직접 서술하게 하는 개방형 질문형태률 취하였다.

\section{3 자료분석}

CIT 체계는 수집된 데이터률 해석 가능한 일반적인 항목으로 분류한 후 다시 비숫한 세 부 하위 항목들로 범주화 시킨다. 본 연구에서는 Bitner et al.(1990)이 개발해서 Hof Iman et al (1995)이 사용했던 범주화 형식을 대부분 따르고 있다.

수집된 자료를 분석하여 범주화하고 코딩, 해석하는 과정온 사건형태로 기록된 방배한 서술형 자료를 세심하게 분류하여야 하기 때문에 많은 시간과 노력을 요하며, 연구자 개인 의 주관성야 다뿐허 개입되게 된다. 그러므로 수집된 자료룰 분석해야 하는 조사의 경우 연 구자돌에 대한 교육은 신뢰성과 타당성 확보를 위해 아주 중요하게 다루어야 할 부분이다 
(Krippendorff 1980; Weber 1985). 따라서 본 연구에서는 자료 분석에 대한 신뢰성을 확보하 기 위해 먼저, CIT를 이용하여 중요한 사건들을 범주화하는 방법을 잘 알고 있는 저자들이 직접 자료를 분석하였다. 몇 차례의 토론을 거친 후 의견이 일치되는 자료들에 대해 동일한 주 실패유형(main category)으로 범주화 하였다. 서비스 실패롤 발생시키는 결정적인 사건 들은 단일항목으로 발생하는 경우도 있지만 이는 극히 소수에 불과하며, 대부분의 경우 복 합적으로 발생할 뿐만 아니라 국내에는 CIT와 관련한 기존의 연구가 거의 전무하기 때문에 실패유형을 분류하는 과정에서 많은 어려움이 있었다. 다음으로, 범주화가 제대로 이루어긴 것인가푤 확인하기 위해 다시 자료들을 주의 깊게 읽은 다음 재 분류작업을 촣 3 회 반복실 시 하였다. 재 분류과정에서 이전과 다르게 분류된 자료에 대해서는 두 조사자가 토론을 거 친 후 하위범주 분류 시 확정하는 방법올 취하였다. 하지만 몇 번의 토론을 거쳐도 의견말 치를 보지 못한 자료들은 분석에서 제외되었다.

주 실패유형을 범주화 하는 과정에서 세 가지의 실패유형에 대해 두 분석자간 $94 \%, 92 \%$, 95\%의 의견일치를 불 수 있었다. 다음으로 각각의 주 실패유형의 하위범주에 속하는 결정적 인 사건들올 분류하는 과정예서 Bitner et al. (1990)의 경우는 하위범주를 12 개로 분류하였 으나 본 연구에서는 두 연구자가 설문에 대한 답변내용을 충분히 읽어본 결과 11 개의 하위 범주로 축소할 수 있었다. 하위범주(subcategory)를 분류하는 과정에서 고객의 불만족을 먀 기한 결정적인 사건들이 복합적으로 발생한 경우는 고객의 불만족에 결점적인 역할을 한 사 건에 초점을 두었다. 서비스 실패유형의 하위 범주 분류과정에서는 두 분석자간 $94 \%$ 의 의견 일치를 보여 높은 분석자간 신뢰도를 확보할 수 있었다.

세 개의 주 실패유형은 Bitner et al. (1990)이 호텔, 음식점, 항공사와 관련된 산업분야를 대상으로 실시한 연구에서 개발되웠으며 각각은 서비스 제공 실패, 표현하거나 표현하지 않 은 포객요구에 대한 대옹, 즉각적이지 않고 문제 해결을 해주지 않는 종업원의 행위로 분류 된다. 아래의 <그립 1>은 본 연구에서 고객이 느낀 서비스 실패유형을 분류하는 근거가 딘 과정으로 Bitner et al. (1990)의 내용을 일부 수정하여 본 연구에 맞게 설정한 것이다. 이를 Hof fman et al. (1995)의 실패유형으로 설명하면, 그룹 1에 포함되는 내용은 음식서비스와 같 은 핵심서비스와 관련된 것이다. 그륩 2에 포함되는 내용은 고객의 요구에 대한 좋업원의 대응과 관련된 것으로 이 부분은 고객이 종업원에게 그들만의 톡별한 오구를 했을 때 종입 원이 이를 제대로 수행해 주지 못했기 때문에 발생한 고객의 불만족과 관련된 부분이다. 고 릅 3 은 즉각적이지 않고 문제 혜결을 해주지 않는 종업원과 관련된 부분으로 무례한 행동을 하거나, 고객을 무시하거나, 혹은 고객의 말에 주의률 기울이지 않는 종업원들의 행위로 인 해 고객이 불만족을 느끼계 된 경우이다. 
<그립 1> 서비스 실패를 가겨온 결정적인 사건에 대한 분류과정

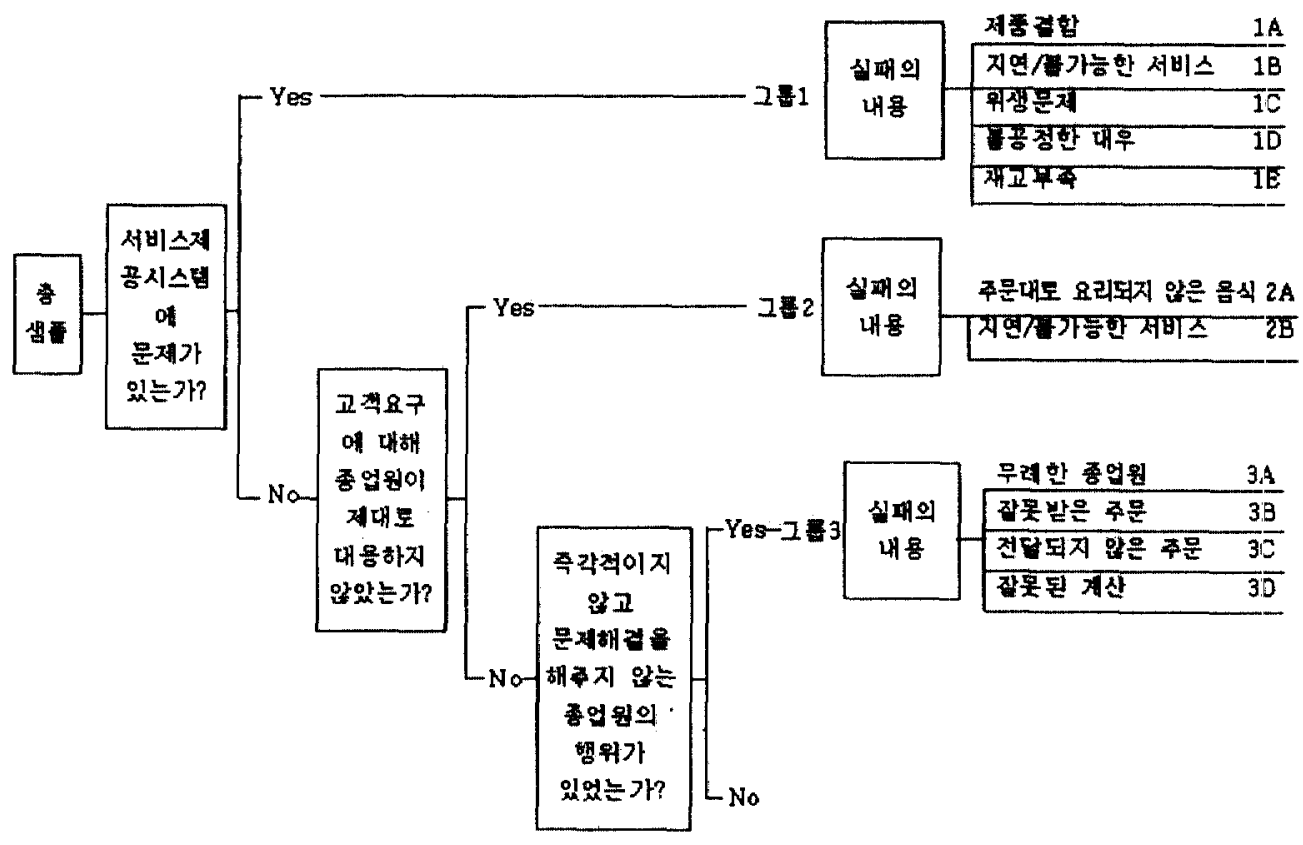

출처 : Bither, Mary Jo, Benard H. Booms, and Mary Stanfield Tetreault (1990), "The Service Encounter: Diagnosing Favorable and Unfavoable Incidents," Journal of Marketing, 54 (January), 71-84.

본 연구에서 세 개의 주 실패유형 내에 존재하는 하위범주는 그룹1에 대해 5 개, 그룹2애 대해 2 개, 그륩3에 대해 4 개로 구성되어진다.

다음에 이어질 <표 2>, <표 3>, <표 4>는 본 연구에서 직접 수집한 서비스 실패의 사례를 <그립 1>의 서비스 실패 분류과정에 따라 세 개의 주 실패유형과 각 하위유형으로 분류한 예이다. 아래의 사례에서 알 수 있듯이 서비스 실패를 일으키는 결정적인 사건들은 복합적 으로 발생하는 경우가 많았으나 가장 핵심적이며 비중을 많이 차지하는 사건을 기준으로 범 주화 된 것이다. 
<표 2> 그룹 1의 예 : 서비스 제공 시스템의 실패

\begin{tabular}{|c|c|}
\hline 하 위 유 형 & 사 \\
\hline $\begin{array}{l}\text { 1A. 제 품 결 함 } \\
\text { (23세 남성) }\end{array}$ & $\begin{array}{l}00 \text { 식당에서 돌솥 비밤밥을 시켰는데 그 속에서 벌레가 나왔다. 안 } \\
\text { 먹겠다고 애기를 했더니 종업원이 더 화를 내며 가져가는 것이었 } \\
\text { 다. 더군다나 주인아저씨는 아무런 미안하다는 말조차 없었다. 다 } \\
\text { 시는 그 음식점에 가기 섫고, 내 주위의 모든 사랃둘에게까지 가지 } \\
\text { 말 것을 애기하고 있다. }\end{array}$ \\
\hline $\begin{array}{l}\text { 1B. 지연/불가눙한 } \\
\text { 서비스 } \\
\text { (26세 남성) }\end{array}$ & $\begin{array}{l}00 \text { 술집에서 있었던 일이다. 안주를 시켰는데 } 30 \text { 분이 지나도 나오 } \\
\text { 질 않는 것이었다. 중간에 우리는 그만 가려고도 하였지만 오기로 } \\
\text { 버티고 있는 심정이었다. 들어갈 때부터 늦은 시간인데도 손닙이라 } \\
\text { 곤 우리밖에 보이질 않았는데도 종업원은 사과도 하지 않았다. 너 } \\
\text { 무 불쾌했다. }\end{array}$ \\
\hline
\end{tabular}

1C. 위 생 문 제 냉면 집에서 식사를 하던 중 주방 쪽예서 쥐 한 마리가 약올 먹었 (34세 남성) 는지 비틀거리면서 기어 나왔다. 주인은 그걸 발견하고 손에 비닐 을 끼우고 쥐를 잡았다. 쥐의 비명소리를 들으며 손님들은 즐겁계 (?) 식사를 할 수 있었다. 냉면의 맞은 육수인데, 갑자기 그 옥수 의 재료가 궁금해 겼다. 혹시 쥐?

1D. 불공정한 대우 00 에 있는 민물장어 구이 집에서 있었던 일이다. 손님이 많았가 때 (25세 남성) 문에 6명이 한 테이블에 같이 않았는데 기다리는 시간이 길어졌다. 우리보다 늦게 온 손님에게 밀반찬이 먼저 서빙이 되는 것을 보고 있던 우리 할머니깨서 한 소리 하셨다. 할머니께서 언성을 높이시 자 일하는 아주머니는 지지 않으려고 더 큰 소리를 냈고 결국 나와 아주머니의 싸움이 되었다. 그 식당을 가려는 주위 사람들에게 제 발 그곳에 가지 말라고 권하고 있다.

1E. 재 고 부 족 전에 맥도날드에서 어린이 날 행사로 세트 메뉴 당 장난감을 주는 (22세 여성) 행사를 한 적이 있었다. 오랜만에 놀러 온 조카가 그걸 갖고 싶어 하기에 일부러 세트메뉴를 시켰는데 장난감이 다 멀어졌다고 말했 다. 그래서 전후 사정을 말했음에도 불구하고 그 점원은 미안해 하 지도 않고 없는 결 자기보고 어쩌나는 식으로 대답했다. 이런 사소 한 일조차 처리하지 못하는 점포라면 다시는 가고싶지 않았다. 
<표 3> 그룸 2의 예 : 고객요구에 대한 종업원 대웅

\begin{tabular}{|c|c|}
\hline 하 위 유 형 & 불 만 족 \\
\hline $\begin{array}{l}\text { 2A. 주문대로 요리 } \\
\text { 되지 않은 음식 } \\
\text { (34세 여성) }\end{array}$ & $\begin{array}{l}\text { 자주 가는 음식점에서 있었던 일이다. 평소 그 음식점의 음식이 짜 } \\
\text { 기 매문에 싱겁게 해 달라고 부탁을 했지만 나온 음식은 여전히 짜 } \\
\text { 욌다. 자주 오는 고객의 부탁도 하나 제대로 신경을 쌔 주지 않다니 } \\
\text { 이제 음식점을 바폐야겠다고 생각했다. }\end{array}$ \\
\hline $\begin{array}{l}\text { 2B. 좌 석 배 치 } \\
\text { (30세 여성) }\end{array}$ & $\begin{array}{l}\text { 종업원이 음식을 식탁에 던지둣이 놓고 피크타임 때라서 자리가 모 } \\
\text { 자란다는 이유로 나의 의견은 물어보지도 않고 모르는 손님을 망연 } \\
\text { 한 듯이 동석 시켰다. 상당히 기분이 나뺐고 식사률 편하게 할 수도 } \\
\text { 없었다. }\end{array}$ \\
\hline
\end{tabular}

<표 4> 그롭 3의 예 : 즉각적이지 않고 문제 해결을 해주지 않는 종업원의 행위

\begin{tabular}{|c|c|}
\hline 하 위 유 형 & 불 만 족 \\
\hline $\begin{array}{c}\text { 무례한 종업원 } \\
\text { (47세 여성) }\end{array}$ & $\begin{array}{l}\text { 비 오는 날 어느 음식점에 갔는데 가게에는 손님이 없었다. 우리 } \\
\text { 가 가게에 들어서자 앉아서 놀고 있던 종업원들이 인상을 찌푸리 } \\
\text { 며 카운터 쪽으로 가면서 “ 에이 XX 손넘이 오구 난리네..." 라.고 } \\
\text { 말 했다. 그리고는 그룻을 놓을 때 툭둑 던지면서 성의 없게 서빙 } \\
\text { 을 하고 짜중스런 표정으로 대했다. 그 집이 망해 버렸으면 좋겠 } \\
\text { 다. }\end{array}$ \\
\hline
\end{tabular}

3B. 잘못 받은 주문 스퐈게티를 시켰는데 옆 테이블과 바꺼어져 나온 모양이었다. 치 (45세 여성) 즈가 덮혀 있어서 별 구분이 가지 않아 몇 번 집어먹었는데 조금 뒤 옆 태이블과 바뀌었다고 다시 바꿔주는데 그 쪽도 몇 번 집어 먹은 흔적이 있었다. 너무나 불례했다. 다시는 스파게티를 먹기도 싫어졌다.

3C. 전달되지 않은 친구들과 00 에 있는 한 피자가게에 들렀다. 워낙 유명한 곳이라 주문 기대률 하고 갔었으나 주문한지 40 분이 지나도록 우리의 음식은 (24세 납성) 나오질 않았다. 처음에는 주문이 밀려서 그런가 보다 생각했는테 우리보다 늦게 온 두 팀이 식사를 하자 종업원을 불러 자초지종을 따져보니 바빠서 주문하는 걸 깜박 했다는 것이었다. 이럴 수가 있는가?

3D. 잘못된 계산 음식을 먹고 나오면서 계산을 하고 나오려는 테 예상한 금액과 계 (52세 여성) 산된 금액이 달라丸다. 결국 내가 한 계산이 맞았는데 기분이 나쌨 다. 조금 더 별어 보려고 손님을 속이는 것 같은 느낌이 돌었다. 
각 하위범주의 내용들을 살펴보면, $1 \mathrm{~A}$ 인 재품결함은 핵심 서비스인 제품자체가 잘못된 것 으로 예를 든다면, 음식 속에 벌레가 들어 있었다거나, 음식이 너무 짜거나 맵게 조리 되었 다든지, 다른 고객에게 한번 제공되었던 음식이 다시 제공된 것을 의미한다. $1 \mathrm{~B}$ 인 지연/볼 가능한 서비스란 음식이 나오기까지 기다리는 시간이 너무 길었지만 이에 대한 그 어떤 설 명도 없었기 때문에 불만족헸거나, 음식을 먹올 자리가 없어 서비스를 이용하지 못한 것이 다. $1 \mathrm{C}$ 인 위생문제란 고객이 서비스를 이용하는 도중에 발생할 수 있는 것으로 께끗하지 돗 한 식기류, 청결하지 못한 종업원 복장 - 가게상태, 불결한 가게의 집기류, 음식점에 벌레 나 쥐가 돌아다닌 경우이다. 그리고, $1 \mathrm{D}$ 인 불굥정한 대우는 본인보다 늦게 온 고객에게 옫 식이 먼저 제공되거나, 나이가 어리다고 함부로 대우를 한다거나, 또는 대금결제를 위해 신 용카드를 제시하였지만 이를 거절 당한 경우들이다. 그룹1의 마지막 하위 부분인 $1 E$ 는 재고 부족으로 인해 주문한 음식을 만들 수 없어 서비스률 받지 못한 경우이다.

$2 A$ 인 주문대로 요리되지 않은 음식의 경우는 고객의 요구를 수행해 주지 않은 것으로 예 를 들면, 채식주의자가 고기를 야채로 대체해 줄 것을 요구하였지만 야채가 아닌 고기가 그 대로 게공된 경우를 의미한다. $2 \mathrm{~B}$ 인 좌석배치란 훕연자률 금연 석에 앉힌다든지, 손님예게 한 마디의 양해도 없이 다른 고객과의 합석을 강요한다거나, 손님이 원하는 자리롤 배정헤 주지 않은 경우, 혹은 예약올 했으나 이것이 접수되지 않은 경우들이다.

$3 A$ 인 무레한 종업원의 경우는 고객이 생각햐는 기대를 저버리는 종업원의 행동으로 무례 하거나 좋지 않온 행동을 의미하며, $3 \mathrm{~B}$ 인 잘못 받은 주문이란 고객이 주문한 음식이 아니라다른 음식을 가져온 경우이며, $3 \mathrm{C}$ 인 전달되지 않은 주문은 고객이 주문한 음식이 아예 접수 되지 않아 음식이 고객에게 전달되지 않은 경우이다. 그리고 마지막인 $3 \mathrm{D}$ 의 잘못된 계산은 계산이 정확하지 않은 경우를 의미한다.

\section{4. 연구 결과}

\section{1 실패유형과 고객이 느끼는 서비스 실패수준}

아래의 <표 5>는 <그림 1>의 분류과정에 따라 서비스 실패를 가져온 결정적인 사건을 분 류해 놓은 것이다. 서비스 실패유형은 응답자들이 음식점에서 겸은 좋지 않은 서비스 경헙 에 따라 3 개의 주 그룹과 11 개의 하위범주로 나누고 그에 대한 서비스 실패 빈도, 실패비율, 그리고 각 실패에 대해 서비스 제공자 측이 제공한 서비스 복구에 대해 고객들이 느끼는 평 균 복구수준, 점포에 대한 계속이용 비율을 나타내고 있다. 
<표 5> 서비스 실패 유형

\begin{tabular}{|c|c|c|c|c|c|}
\hline 서비스 실패 유형 & 개수 & x & 실 패정도 & 복구정도 & $\begin{array}{r}\text { 계속 우 } \\
\text { (q) }\end{array}$ \\
\hline 서비스 제퐁 시스탬의 & 실 패 & & & & \\
\hline 재품결함 & 199 & 26.93 & 7.93 & 3.30 & 21.61 \\
\hline 지연/불가능 한 서비스 & 94 & 12.72 & 7.80 & 3.09 & 24.47 \\
\hline 위생문제 & 81 & 10.96 & 7.54 & 2.99 & 23.46 \\
\hline 불공정한 대우 & 35 & 4.74 & 7.60 & 3.32 & 25.71 \\
\hline 재고 부족 & 9 & 1.22 & 8.11 & 2.67 & 11.11 \\
\hline 그륨 1 소계 & 418 & 56.56 & & & \\
\hline
\end{tabular}

그룹 2 고객요구에 대한 종업원 대웅

주문대로 요리되지 않은 음식

$4 \quad 0.54$

8.00

4.00

0.00

좌석베치

18

2.44

7.72

3.44

22.22

그룹 2 소계

22

2.98

그룹 3 즉각적이지 않고 문제 해졀을 해주지 않는 종업원의 행위

무례한 종업원

잘못 받은 주문

전달되지 않은 주문

잘못된 계산

그룹 3 소계

총 계

1 실패정도는 1 (사소한 실수)에서 10 (심각한 실수)으로 측정뒴

2 복구정도는 1(아주 나핬다)에서 10(아주 좋았다)으로 측정됨

3 계속이용 정도는 서비스 실패 후에도 계속 이용하는 비율임

$\begin{array}{rrrrr}243 & 32.88 & 7.79 & 2.74 & 21.40 \\ 37 & 5.01 & 7.54 & 3.81 & 43.24 \\ 11 & 1.49 & 8.45 & 2.91 & 18.18 \\ 8 & 1.08 & 7.75 & 4.00 & 50.00\end{array}$

$299 \quad 40.46$

739

<표 5 의 서비스 실패유형 중 $1 \mathrm{~A}$ 부분인 제품과 관련된 실패는 전체의 $26.93 \%$ 이었으며, 서비스 실패의 평균은 7.93으로 매우 심각하게 나타났을 뿐만 아니라 복구정도가 평균 3.30 으로 고객듈이 복구에 만족하지 못하는 것으로 나타났다. 그리고, 본 연구에서 제품과 관련 된 실패로 가장 많이 발생한 것온 음식 속에 벌레가 들어 있는 경우였다. $1 \mathrm{~B}$ 부분인 지연/ 
불가능한 서비스와 관련한 실패는 전체실패 중 $12.72 \%$ 를 차지하였다. 실패의 정도는 평고 7.80 으로 제품결함에서 온 실패의 심각성 정도보다는 낮지만, 복구정도가 평균 3.09 로 복구 에 대한 불만족은 더 높게 나타났다. $1 \mathrm{C}$ 부분인 청결과 관련된 실패는 총 실패 중 81 개로. 약 $11 \%$ 를 차지하였다. 청결과 관련된 실패정도는 평균 7.54 , 복구정도는 2.99 로 아주 좋재 않은 것으로 집계되었다. $1 \mathrm{D}$ 인 불공정한 대우와 관련해서 발생한 실패는 전체의 $4.7 \%$ 로 실 패정도는 평균 7.60 , 복구정도는 3.32 인 것으로 집계되었다. 그룹 1 에 속한 마지막 실패유 형인 $1 \mathrm{E}$ 의 재고 부족은 전체에서 차지하는 비율온 $1.22 \%$ 로 가장 낮았지만 실패정도는 8.11, 복구정도는 2.67로 서비스 실패 유형들 중 복구에 대한 불만족 정도가 가장 높았다. 그룸 1 과 관련한 서비스 실패가 발생했을 경우 점포 측에서 서비스 실패 복구롤 위한 대웅을 하였 을 때 고객이 느끼는 서비스 복구수준은 그룹평균 3.07 로 아주 좋지 않게 느끼는 것으로 나 타났다.

그릅 1에서 나타난 결과를 Hoffman et al.(1995)의 결과와 비교해 볼 때 그들의 연구에서 는 실패의 심각성 정도는 재고부족, 청결, 지연/불가능한 서비스, 제품관련 실패, 불공정한 대우 순으로 나타넜으나 본 연구에서는 재고부족, 제품관련 실패, 지연/불가능한 서비스, 불공정한 대우, 청결 순으로 나타났다. 하지만 재고가 부족할 경우 두 연구 모두에서 고객 들이 느끼는 실패의 심각성의 정도는 가장 높았다.

그릅 2는 고객요구에 대한 종업원의 대응과 관련된 부분으로 총 실패의 약 $3 \%$ 를 차지하뎠 다. 이 그륩에 속하는 두 가지 유형은 주문대로 요리되지 않은 음식과 자리배치이다. 본 뎐 구에서 이 유형과 관련된 실패는 전체 실패의 2.44 를 차지하고 실패의 심각성 정도는 7.72 , 고객이 느끼는 복구정도는 3.44로 Hoffman et al. (1995)의 연구와 거의 동일한 결과를 보다 주었다.

마자막으로, 그륩 3 은 즉각적이지 않거나 문제 해결을 해주지 않는 종업원의 태도와 관현 된 것으로 전체 실패의 $40.46 \%$ 로 나타났다. 그 중 약 $33 \%$ 는 종업원의 무례한 태도와 관련 된 것이었다. $3 A$ 인 종업원의 무례한 태도와 관련된 실패의 심각성 정도는 7.79 , 복구정도는 2.74 로 고객이 느끼는 실패의 심각성 정도도 높았고, 서비스 제공자 측의 대응에 대해 고객 들이 느끼는 복구에 대한 느낌도 아주 나쁜 것으로 나타났다.

\section{2 서비스 복구 유형과 복구에 대한 고객의 지각}

아래의 <표 6>은 본 연구에서 조사된 서비스 실패 유형과 관련된 음식점의 서비스 복구내 용에 관한 것으로 서비스 복구별 빈도, 전체 복구에 대한 비율, 각 복구와 관련한 평균 실 패정도, 평균 복구수준, 점포의 서비스 복구가 좋거나 좋지 않게 인식된 빈도 그리고, 각 각의 서비스 복구와 관련하여 서비스 실패 후에도 그 점포를 계속 이용하는 정도로 구성뎌 어 있다. 본 연구에서 서비스 복구 내용은 부가음식의 무료제공, 주문한 음식 무료제공, 할 인, 매니저의 조정, 다른 음식으로 대체, 동일 음식으로 교환, 사과, 무반옹, 무관심 둥 챵 11가지로 분류되었다. 
<표 6>서비스 복구

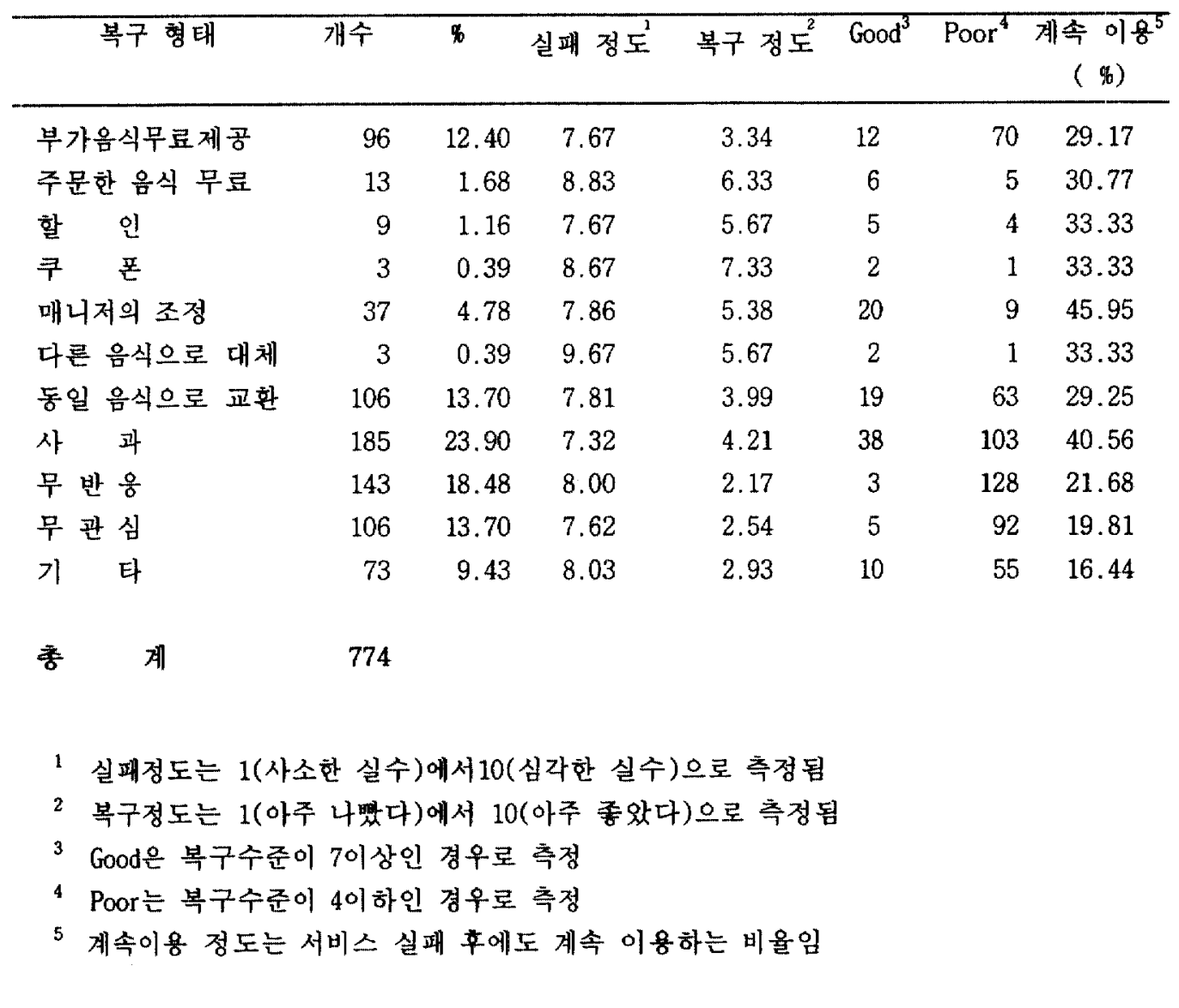

다양하계 나타난 서비스 복구 형태들을 <표 6>에 나타나 있는 몇 개의 복구형태로 단순화 시키는 과정에서 Hoffman et al. (1995)은 CIT률 이용하여 서비스 복구형태롤 점포 측에서 고 객의 불평에 대해 아무런 대웅을 하지 않은 nothing을 포함하여 8가지로 단순화 시켜놓았다. 하지만 본 연구에서는 nothing이 두 가지 형태로 나타넜다. 하나는 점포 측의 잘못은 인정 하지만 아무런 대웅울 하지 않은 경우이고, 나머지는 아예 점포 측의 잘못조차도 인정하지 않은 경우이었다. 이 두 유형올 동일하게 취급해야 할 것인지, 아니면 다르게 취급해야 할 것인지률 두고 연구자들이 여러 번의 토론을 거친 결과 nothing을 무반웅과 무관심으로 이 분하는 것에 의견일치률 보았다. 그리고 어느 부분에도 해당되지 않는 복구들은 기타로. 묶 어 일괄 처리합으로서 복구형태가 11 가지로 확장되었다.

서비스 실패 복구예 나타나있는 부가음식 무료제 공은 전체 서비스 복구에서 $12.40 \%$ 를- 차 지하였다. 부가음식 무료제공이란 서비스 제공자가 서비스 실패를 복구하기 위해 고객에게 콜라, 사이다 둥의 음료수나 마론안주, 야채 샐러드 등을 무상으로 제공하는 것을 말한다. 부가 음식이 무료로 제공되었을 경우 고객이 느끼는 복구수준의 평균은 3.34 로 나타나 기업 의 복구에 대해 고객이 느끼는 수준은 매우 낮옴을 알 수 있다. 고객의 불만에 대한 복구형 
태로 쿠폰이 제공되었을 때 고객들이 느꼈던 복구정도는 7.33 으로 나타나 단일 복구유형으 로는 복구수준이 가장 높았다.

<표 6>을 통해 알 수 있듯이 대개 업주 측에서 서비스 복구를 할 경우 고객의 불만족은 줄어들었다. 하지만 무반웅, 무관심과 기타의 경우는 고객이 느끼는 불만족의 정도가 더 좀 아졌다. 본 연구에서의 무반웅이란 서비스 제공자가 재공자 측의 잘못을 인정하지만 실패의 복구를 위해서 아무런 행동도 취하지 않은 경우로 전체의 $18.48 \%$ 를 차지하였다. 그리고, 업 주 측의 잘못 자체를 인정하지 않고 당연한 것으로 받아들이며 관심조차 보이지 않는 무판 심은 $13.70 \%$ 로, 고객의 불만족을 복구해 주려는 업주 촉의 노력이 매우 미비함을 알 수 있 다. 또한 사과의 경우는 고객이 느끼는 복구수준이 4.21 이지만 대응밤법이 줗았다고 표현한 사람은 38 명이었다. 이는 사과를 형식적인 사과와 진심 어린 사과로 세분화하지 않았기 대 문에 나타난 결과이다. <표 6>에 하나로 묵여있는 사과를 형식적인 사과와 진심 어린 사과. 로 세분해 보면, 형식적인 사과의 평균 복구수준 3.00 으로 고객이 처음 느낀 서비스 실패보. 다 복구이후 그 심각성이 더 심해졌으나 업주 측에서 진심 어린 사과률 해 주었을 경우에는 복구수준이 7.25로 “아주 좋았다” 에 근접하는 훙미로운 결과를 보여준다.

마지막으로, 기타는 고객을 오히려 이상한 사람으로 취급하거나, 음식물 속에 들어있는 이물질만 제거하고 그대로 먹으라고 강요하거나 업주 측의 책임올 회피한 경우, 주인이 채 임을 종업원에게만 이전시키거나 고객에게 오히려 화를 낸 경우, 유명한 집이니 이 정도의 불편은 당연한 것이라고 여기는 경우, 아예 고객이 불만을 표현하지 않은 경우 등이었다.

서비스 실패가 발생했을 때 점포 측에서 고객에게 제공하는 복구의 유형은 단일항목으폴 발생하는 경우도 있지만 복합적으로 발생하는 경우가 많았다. 그 중 진심 어린 사과와 더불 어 쿠폰이나 부가서비스를 제공한다든지 대기시간에 대한 설명이 주어졌을 때 느끼는 고객 들의 복구수준이 가장 높은 것으로 나타났고, 복구수준이 "좋았다" 로 웅답한 대답의 $79.03 \%$ 가 사과를 포함하고 있었다. 이는 서비스복구에는 무엇보다도 서비스졔공자의 사과가 선행되어야 합을 알 수 있게 해 주는 부분이다.

\section{3 고객들이 바라는 서비스 복구}

본 연구자들은 서비스 제공자가 서비스 실패에 대한 고객 불평에 좀 더 적극적으로 대옹 하는 데 도움이 되고자 Hoffman et al. (1995)에서는 연구되지 않았던 고객들이 바라는 복국 률 알아보았다. <표 7>은 본 연구에서 나타난 고객들이 점포에 기대하는 복구의 내용을 정 리한 것이다. 고객이 점포에 기대하는 복구의 총계는 한 명의 웅답자가 여러 가지 복구 내 용을 기술한 경우도 있기 때문에 응답자의 수보다 딶게 나타나 있다. 고객이 기대하는 복군 는 총 12 가지로 분류되었다. 그 중 고객들이 가장 원하는 복구는 쿠폰 제공이나 부가음식둘 무료제공과 같온 유형적인 복구가 아니라 종업원 및 주인의 진실한 사과이었다(43.66\%). 이 는 웅답자들 중 업주 측에 불쾌한 마음을 토로했지만 아무런 반웅이 없었다든지, 무관심헸 을 경우, 혹은 건성으로 사과를 했을 경우 만약 점포 측에서 진실한 사과를 했더라면 불쾌 합을 극복할 수 있었을 것이라는 응답을 집계한 것이다. 물리적인 복구와 관련되는 부가음 식 무료제공, 주문한 음식 무료제공, 할인, 쿠폰, 다론 음식으로 교환이나 같은 음식으로. 교환 등 물질적인 복구는 고객이 바라는 복구의 $36.97 \%$ 로 나타넜지만, 비용이 둘지 않는 무 형적인 복구인 사과와 실수인정, 시정의사 표현, 상황에 대한 성의 있는 설명은 $57.52 \%$ 이었 다. 그리고 기타에 해당하는 사항으로는 서비스 복구가 너무 만족스러워 더 바랄 것이 없다 
는 옹답이 23명, 나머지는 ' 실패상태가 너무나 심각해서 더 이상 이 점포률 방문하지 않으 면 된다' 는 극단적인 생각 때문에 ' 점포측에 대해 바랄 것이 없다' 고 답한 것들이다. 이 결과률 불 때 고객은 물질적이고 유형젹인 복구보다도 고객의 손상된 감정을 치유하는 뚜형 적인 복구를 더 중시합을 알 수 있다.

<표 ㄱ> 고객이 점포에 기대하는 복구

\begin{tabular}{|c|c|c|}
\hline $\begin{array}{llll}\text { 복 구 내 } & \text { 용 }\end{array}$ & 개 수 & $\%$ \\
\hline 부가음식 무료제공 & 54 & 9.50 \\
\hline 주문한 음식 무료 & 46 & 8.10 \\
\hline 인 & 33 & 5.81 \\
\hline 쿠 폰 & 21 & 3.70 \\
\hline 매니저 중재 & 21 & 3.70 \\
\hline 다른 음식으로 교환 & 5 & 0.88 \\
\hline 같은 음식으로 교환 & 51 & 8.98 \\
\hline 종업원 및 주인의 사과 & 248 & 43.66 \\
\hline 실수인정 & 18 & 3.17 \\
\hline 시정의사표현 & 12 & 2.11 \\
\hline 상황에 대한 성의 있는 설명 & 26 & 4.58 \\
\hline 기 타 & 33 & 5.81 \\
\hline 계 & 568 & 100.00 \\
\hline
\end{tabular}

서비스 실패가 발생한 후 이를 복구합으로써 고객을 만족으로 전환시키는 것도 중요하지 만 그것보다 먼저 처음부터 서비스 실패가 발생하지 않도록 전략적인 예방대책을 마련하는 것이 더욱 중요하다(Bitner et al. 1990). 그러므로 전략적 예방대책 마련을 와해서는 고객 이 점포에 바라는 사항을 알아보는 것이 중요할 것이다. 이에 본 연구에서는 기업의 전략적 예방대책 마련에 도움이 되고자 고객이 원하는 점포 개선 사항을 추가적으로 알아보아 <표 $8>$ 에 정리하였다. <표 8>을 통해 알 수 있둣이 서비스 제공자는 고객에계 관심을 가져야 한 다는 웅답이 전체의 $32.24 \%$ 로 가장 높게 나타낪다. 고객에 대한 관심이란 고객이 점포에 들 어오거나 나가는 경우 관심을 가지고 고객에게 인사률 햐는 것과 고객이 불편한 사항을 말 하기에 앞서 고객에게 어떠한 부족함이나 블편함이 있는 가률 살펴 고객이 요구하기 전에 미리 대옹헤즐 수 있도록 노력함을 의미한다. 다음으로, 종업원의 책임감 제고가 $14.0 \%$ 로 나타넜다. 여기서 중업원의 책임감 재고란 종업원이 주인의식을 가지고 고객을 대해야 합을 의미한다. 대기시간 관리와 관련하여 점포 측이 개선해 주기를 원하는 내용은 주문한 음식 이 제공되기까지 기다리는 동안 음료수률 제꽁하거나, 추가적으로 더 기다려야 하는 시간, 
주문 후 음식이 제공되기까지 걸리는 시간을 고객이 알 수 있도록 정보를 제공해주고, 대기 하는 동안 사과의 말을 고객에게 전해야 한다는 내용이었다. 종업원에 대한 서비스교육온. 전체 요구사항 중 8.9x로 나타났다. 톡히 아르바이트생에 대한 서비스교육예 관심을 기울여 야 한다는 내용이 많았다. 그리고, 고객에게 밝은 표정으로 대옹해야 한다는 내용이 전체의 $18.2 \%$ 룰 차지하였다. 고객은 종업원이나 주인이 고객을 대할 때 언제나 미소 떤 밝은 표정 으로 대해 주기를 원한다는 것올 알 수 있었다.

<포 $8>$ 고객이 원하는 점포 개선 사항

\begin{tabular}{lccc}
\hline 개 선 사 & 항 & 개 수 & \% \\
\hline 고객에 대한 관심 & 108 & 32.24 \\
음식 맛 개선 & 13 & 3.88 \\
종업원의 책임감 제고 & 47 & 14.03 \\
점포의 청결 유지 & 34 & 10.15 \\
대기 시간 관리 & 42 & 12.54 \\
종업원에 대한 서비스교육 & 30 & 8.96 \\
고객에게 친절히 대웅(밝은 표정) & 61 & 18.21 \\
\hline 총 & 335 & 100.00 \\
\hline
\end{tabular}

\section{4 결과의 일반화}

본 연구는 기존의 $\mathrm{CIT}$ 연구와는 달리 통계기법을 통해 좀 더 객관화된 결과를 보여 주고 자 유의수준 0.05 에서 $x^{2}$ 검정과 MANONA, T-test, 회귀분석을 실시하였다. 먼저, 서비스 실 패와 관련한 구전효과에 대해 기술통계를 이용해본 결과 자신이 서비스 실패를 경혐했던 음 식점을 다른 사람에게 권유하겠느냐는 질문에 무 웅답 1.9\%를 재외하고 “ 권한다" 13.2\%, "권하지 않는다" 76.5\%, "가겠다고 하면 극구 말리지는 않겠다" $8.2 \%$ 로 나타났다. 이 중 "권하지 않는다" 로 웅답한 사람들 중에는 "절대 가지 말라고 권유" 하던지, "그 음식점 이 망해버렸으며 좋겠다" 라고 대답한 수도 13.5\%률 차지하는 것으로 나타났다. $x^{2}$ 검정에 서는 고객둘은 성별에 관계없이 $\left(\mathrm{x}^{2}=3.145, \mathrm{P}=0.534\right)$ 자신이 경헙한 것돌을 다른 사람들과 공유하며, 구전내용은 연령 $\left(\mathrm{X}^{2}=20.782, \mathrm{P}=0.014\right)$ 과는 서로 관련성을 가지므로 연령에 따라 좋은 내용과 줗지 않은 내용을 구전하는 차이가 나지만, 성별 $\left(X^{2}=10.702, P=0.098\right)$ 과 교육 수준 $\left(\mathrm{X}^{2}=14.039, \mathrm{P}=0.121\right)$ 에 관계없이 좋은 경험보다 좋지 않은 경헙을 더 많이 구전하는 것으로 나타넜다. 이러한 결과는 인간의 부정성 편향(negativity bias)에 기인하는 것으로 좋은 경험보다는 나빤 경험에 관해 활씬 더 강력한 구전할동을 하며, 서비스실패는 수십 명 의 잠재 고객들에게 기업에 대한 부정적인 인상을 심어주게 됨을 보여주는 것이다(Walker 
1995). 그리고 좋지 않은 경협과 좋은 경협의 구전비율은 $3: 1$ 로 좋지 않은 경험을 좋은 경 협보다 평균적으로 3 배정도 더 많이 구전함을 알 수 있었다. 고객이 느끼는 서비스 실패의 심각성 정도와 점포의 대웅방법과 퐌련된 지각된 복구수준과의 관계를 알아본 회귀분석에서 서비스 실패의 심각성이 강할수록 고객이 느끼는 복구수준은 낮게 나타나 고객의 불만쪽에 대해 점포에서 대용을 하더라도 고객이 느끼는 실수정도의 심각성 여부에 따라 대웅방법의 수준을 달리해야 함을 알 수 있었다 $(\mathrm{t}=-9.366, \mathrm{P}=0.000)$. 다음으로 서비스 실패정도와 고객 이 지각하는 복구수준이 응답자의 성별에 따라 차이가 있는가의 여부를 알아보기 위해 T-test를 실시한 결과 실수정도는 남성 (Mean=7.93)이 여성 $(M e a n=7.38)$ 보다 동일한 실수라도 더 심각하게 느끼는 것으로 나타넜지만 $(\mathrm{T}=2.917, \mathrm{P}=0.004)$, 동일한 복구유형이 주어겼을 때 남성과 여성이 느끼는 복구정도는 차이가 없는 것으로 나타났다 ( $\mathrm{T}=-0.891, \mathrm{P}=0.373$ ). 마지 막으로 동일한 서비스 실패에 대해서 느끼는 심각성정도와 주어진 동일한 복구에 대해 지각 하는 수준을 알아보기 위해 MANOVA률 하였다. MANOVA 결과 고객이 느끼는 서비스 실패의 심 각성과 복구정도는 고객의 교육정도(Wilks의 람다=0.980, $\mathrm{F}=1.503, \mathrm{P}=0.213$ )와 나이(Wilks 의 람다 $=0.076, \mathrm{~F}=1.597, \mathrm{P}=0.189$ )에 따라 차이가 없었다. 따라서 서비스 실페가 발생하였을 경우 고객의 유형에 관계없이 서비스 제공자는 서비스 복구에 최선을 다해야만 할 것이다.

\section{5. 결론 및 향후 연구방향}

본 연구는 $\mathrm{CIT}$ 를 이용하여 고객의 관점에서 서비스 실패/복구를 구체적으로 알하보기 위 해 시도되었다. 하지만 여기서 그치지 않고 Hoffman et al.(1995)의 연구에서는 간과되었던 고객이 바라는 서비스 실패에 대한 복구형태와 점포 개선사항까지 알아봄으로써 서비스 실 패에 대한 사후적인 복구전략 뿐만 아니라 서비스 실패를 미연에 방지할 수 있는 사전 전략 개발에도 유용하게 사용되어질 것이다.

연구 결과 서비스 겁점에서 발생하는 소비자 불만족에 가장 크게 작용한 항목은 중업원의 무례한 행동으로 고객 불만족 원인의 33\%를 차지하였다. 이는 선행 연구인 고객 불만족의 43\%가 무례한 종업원으로 인해 발생한다는 Bitner et al.(1990)의 연구와는 일관되지만, 훙 미롭게도 불만족을 야기시키는 가장 핵심적인 원인이 제품자체의 결함이라는 Hoffman et al. (1995)의 연구결과와는 대조되는 것이다. 다음으로 서비스 복구 부분에서는 종업원 과 관 리자들의 서비스 실패상황에 대한 잘못을 인정하는 진심 어릴 사과와 성의 있는 설명과 같 은 무형적인 복구가 제공되었을 때 복구수준이 가장 높았고 계속 이용울 또한 $46 \%$ 로 가장 높계 나타났다. 이를 통해 불 때 고객들은 무형적인 복구를 다른 복구들 보다 우선 시 합을 알 수 있으며, 이러한 무형적인 복구는 고객이 기업에 바라는 복구의 51\%률 차지하여 iㅜ형 적인 복구를 강조한 기존의 연구와는 대조적인 것이었다(e.g., Tax et al. 1998). 그리고 본 연구에서는 서비스 제공자가 제공하는 복구와 고객이 원하는 복구 간에는 많은 차이가 존재 함을 알 수 있었다. 특히 눌라운 것은 서비스 실패가 발생하였을 때 서비스 제공자가 아무 런 복구대안을 제시하지 않거나, 실패률 실패로 여기지 않고 고객을 이상한 사람으로까지 취급하는 경우가 많이 나타났다. 이는 여전히 판매자 중심적인 입장에서 고객을 대하기 때 문에 발생할 수 있는 행동으로 높아져 가는 소비자의 서비스 기대수준에 역행하는 것 일뿐 만 아니라. 서비스 제공자와 고객의 인식사이에 상당한 사고의 차이가 존재함을 보여주는 것 이다. 
본 연구에서 알아본 고객이 바라는 점포의 개선사항에서는 $75 \%$ 가 종업원과 관련되어 있었 다. 이는 무례한 종업원으로 인한 서비스 실패가 가장 많았던 것을 생각해 볼 때 당연한 결 과라고 여겨진다. 그리고 구전과 관련하여 좋았던 경험을 가족이나 주위 사람들에게 전하는: 비율이 나뽄 경헙올 전하는 비율의 $1 / 3$ 도 채 되지 않는 것으로 나타났다. 이상과 같은 결과 중합해 볼 때 본 연구는 다음과 같은 시사점을 제시할 수 있다.

첫째, 가장 빈번하게 발생할 수 있는 서비스 실패를 예방하기 위해 서비스 제공자는 재고 관리 시스템을 운영하고 이롤 철저히 관리하여야 하며, 고객의 대기시간에 관한 적절한 관 리로 불공정하계 대우 받는다는 느낌을 없앨 수 있어야 한다. 이를 위해서는 병목시간에 대 한 종업원 운영 계획이 수립되어야 한다. 그리고. 고객에게 예상 대기시간과 대기가 발생할 수밖에 없는 이유를 설명하여야 하고, 대기를 해결하기 위해 서비스 제공자가 노력하고 있 다는 것을 보여줌으로쎠 서비스 실패률 에방할 수 있을 것이다.

둘째, 서비스 접점 종업원에 대한 철저한 서비스 교육이 이루어겨야 한다. 서비스 실패의 $33 \%$ 가 종업원의 무례합으로 인해 발생하고 고객이 원하는 기업의 개선사항의 대부분이 종업 원과 관련되어 있으므로 종업원에 대한 철저한 서비스 교욱을 통해 항상 관심을 가지고, 밝 은 표정으로 고객을 대함으로서 처음부터 서비스 실패가 발생하는 것을 예방할 수 있을 것 이다.

셋째, 고객의 입장에서 모든 것을 생각할 수 있는 서비스 마인드가 필요하다. 높아져 가 는 소비자의 기대수준애 현실적으로 부옹하기 위해서는 서비스실패가 일어나지 않도록 사전 관리를 철저히 하는 것이 무엇보다도 중요하겠지만, 서비스 특성상 어쩔 수 없이 실패가 빌 생하게 되더라도 고객의 기대와 요구에 합당한 복구를 해 줌으로써 불만족한 고객울 만족한 고객으로 전환시켜 계속적인 재 방문을 유도하고 나아가 신규고객을 창출하게 합으로써 징 기적인 입장에서 기업의 이익증대를 가져오게 할 수 있어야 한다.

넷째, 무형적인 서비스 복구전략을 효율적으로 활용하여야 한다. 서비스 제공자는 유형적 인 복구애 앞서 진심 어린 사과나 서비스실패에 대한 자세한 설명과 같은 무형적 서비스 복 구 전략을 효율적으로 이행함으로써 서비스실패로 인해 상처 받은 고객의 마음을 치유하고 기업에 대한 신뢰감을 되찾게 한다면 유형적인 복구비용을 상당히 줄일 수 있게 될 것이다.

다섯째, 일선 종업원에 대한 어느 정도의 재량권(empowerment)이 부여되어야 한다. 핵심 서비스인 제품의 결함으로 인한 서비스 실패가 발생했을 경우 서비스 접점 종업원들은 고객 의 불만에 대해 어떻게 대응해야 할 것인가를 신속하게 결정하고 대응해야 하기 때문에 적 정한 수준의 재량권이 부여되어야 한다.

여섯째, 불평하지 않은 고객들이 대부분 만족한 고객이라는 오류에 빠져서는 안 된다. 본 연구에서 불평하지 않은 고객 중예는 불평올 하더라도 서비스 졔공자가 이에 대한 개선을 해 주지 않을 것이라고 생각하거나 다음부터는 이 곳을 이용하지 않으면 된다는 극단적인 생각을 가지고 있는 고객들이 많았던 점올 감안해 볼 때 서비스 재공자는 불평하지 않는 고 객의 대다수가 만족한 고객이라고 간주해서는 안 될 것이다.

일곱째, 불평하는 고객을 감사하게 대할 수 있어야 한다. 고객이 불평을 하는 것은 서비 스 제공자에 대해 관심을 가지고 있기 때문이다. 그들은 기업이 고쳐야 할 관리적인 문제를 보수를 받지 않고 킨설턴트 해주고 진단해 줄 뿐만 아니라 기업이 서비스 실패를 복구할 수 있는 기회를 제공해 주는 것이다(Hoffman and Bateson 1997). 그러므로 고객의 불평을 정보 로 이용한다면 불만족한 고객을 만족으로 전환시키고, 다른 기업으로의 전환행동과 좋지 않 은 구전을 예방할 수 있을 것이며, 차후 동일한 실패가 발생하지 않도록 할 수 있을 것이 
다.

여덟째, 구전관리를 위한 체계적인 전량ㅇ 수립되어져야 한다. 구전과 관련하여 나뽄 경 헙을 이야기하는 고객이 좋은 경헙을 타인에계 전하는 고객 보다 거의 3 배에 달하는 것으로 조사되어 Walker(1995)의 연구와 유사한 결과률 보여주있다. 여기에서 유의하여야 할 것은 이전의 고객둘은 그들의 부정적인 경험에 대해 가족, 동료 또는 친구들에게 구전하는 것에 한정되었지만 이제는 인터넷과 같은 매체가 발달하게 됨에 따라 애전보다 휠씬 많은 사람들 이 불만족한 그들의 경험을 궁유할 수 있계 되어 더 강력한 파급효과률 가질 수 있다는 것 이다(Stauss 1997). 그리고 한국의 인터넷 사용자수가 97년에 비해 2배 이상 중가한 현실을 감안해 볼 때 적정한 수준의 서비스 복구률 받지 못한 고객은 매체를 통해 그 때 받았던 나 쁜 경헙을 에전과는 비교가 되지 않을 정도로 주위의 보다 많은 사랍들에게 전달할 것임으 로 서비스 관리자돌은 고객의 구전 관리를 위한 체계적인 전략을 수립하여야 한다.

본 연구의 아쉬움을 든다면 음식점이라는 단일분야를 대상으로 하였기 때문에 다양한 서 비스 분야에 대한 고객의 소리률 들을 수 없었다는 점이다. 그러므로 향후에는 다양한 분 야에 CIT를 이용하여 서비스 실패와 복구에 대해 살펴볼 필R가 있다. 그리고 서비스 실패 를 경헙한 정확한 기간을 표시하지 않아 서비스 실패에 대해 느꼈던 고객의 감정이 얼마나 오캣돟안 지속되는 가률 알아보지 않았으며, 음식점의 수준 또한 고려하지 않았기 때문-에 이 점들을 고려한 연구 또한 이루어져야 할 것이다. 홍미븝게도 서비스 실패률 유발하는 결정적인 사건의 비중이 Hoffman et al.(1995)과 Tax et al.(1998)의 연구 절과에서는 해심 제품에서 높게 나타넜지만, 본 연구에서는 중업원의 태도에서 높게 나타넜다. 이것이 우연 에 의해서인지, 아니면 미국과 한국이라는 문화적 차이에 의해 필연적으로 나타날 수바에 없었던 것이었는가에 대한 확인이 앞으로의 연구에서는 이루어져야 할 것이다. 


\section{<참고문헌>}

류미현, 이승신 (1997), " 소비자문제 및 불만족에 따론 대웅행동," 대한가정학회지, 35(5), 195-211.

윤성욱 (2002), "The Role of Relationship Quality in the Case of Service Failure," 경 영연구, 17(1), 181-199.

이기춘, 조회경 (1996), “의료서비스에 대한 소비자 불만족, 불만호소 행동 및 재구매 의 도 : 종합병원을 중심으로," 소비자학연구, 7(2), 87-108.

이수형, 이재록, 양희진 (2001), “ 관계형성 유지예 대한 신뢰와 만족의 매개역할에 관한 연구," 마케팅관리연구, 6(1), 1-32.

이옹기 (2001), " 고객접점 종업원의 친 사회적 행위예 대한 고객지각이 종업원 서비스품질

평가, 고객만족과 고객의 자발적 행위에 미치는 영향, " 마케팅연구, 16(3), 105-125. 이유재 (2000), "고객만족 연구에 관한 종합적 고찰," 소비자학연구, 11(2), 139-166. 이은희, 민남희 (2000), "대학생의 학원 교육서비스에 대한 소비자불만족과 대웅행동," 소비자학연구, 11(4), 85-109.

이인구, 김종배, 이문규 (2000), “ 지각된 서비스 품질, 소비자 태도, 재 이용 의도 사이의 인과관계 모형," 한국마케팅저널, 2(3), 44-63.

장홍섭, 류갑경 (2002), “불평에 대한 기업반응과 불평 처리 후 소비자 반응," 한국전락마

케팅확회, 춘계학술대회 발표논문, 69-90.

Bejou, David, Bo Edvardsson, and James P. Rakowski (1996), “ A Critical Incident Approach to Examining the Effects of Service Failures on Customer Relationships: The Case of Swedish and U.S. Airlines," Journal of Travel Research, (Summer), 35-40.

Bitner, Mary Jo (1990), "Evaluation Service Encounters: The Effect of Physical

Surrounding and Employee Response," Journal of marketing, 54 (January), 71-84.

Bitner, Mary Jo, Bernard H. Booms, and Lois A. Mohr (1994), "Critical Service Encounters:

The Employee's Viewpoint," Journal of Marketing, 58 (October), 95-106.

Bitner, Mary Jo, Bernard H. Booms, and Mary Stanfield Tetreault (1990), "The Service

Encounter: Diagnosing Favorable and Unfavorable Incidents," Journal of Market ing, 54 (January), 71-84.

Brown, Stephen W. (1997), "Service Recovery Through IT," Marketing Management, 6 (3), 25-27.

Chung, Beth and K. Douglas Hoffman (1998), "Critical Incidents: Service Failures That Mat ter Most," Cornel/ University, Hotel and Restaurant Administration Quartery, (June), 66-71.

Dolen, Willemijn V., Jos Lemmink, Jan Mattsson, and Ingrid Rhoen (2001), "Affective Consumer Responses in Service Encounters: The Emotional Content in Narratives of Critical Incidents," Journal of Economic Psychology, 22, 359-376.

Edvardsson, Bo (1992), "Service Breakdowns: A Study of Critical Incidents in an Airline," International Journal of Service Industry management, 3 (4), 17-29.

Goodwin, Cathy and Ivan Ross (1992), “ Consumer Responses to Service Failures: Inf luence of Procedural and Interactional Fairness Percept ions," Journal of Business Research, 
$25, \quad 149-163$.

Hof fman, K. Douglas and John E. G. Bateson (1997) Essentials of Services Marketing, The Dryden Press Harvourt Brace College Publisher.

, Scott W. Kelley, and Holly M. Rotalsky (1995), " Tracking Service Failures and

Employee Recovery Efforts," Journal of Services Marketing, 9 (2), 49-61.

Jagdip, Singh, and Robert E. Wilkes (1996), "When Consumers Complain: A Path Analys is

of The Key Antecedents of Consumer Complaint Response Est imates," Journal of the Academy of Market ing Science, 24 (4), 28-30.

Johnston, Robert (1995), "Service Failure and Recovery: Impact, Attributes and Process," Advances in Services Market ing and Management, 4, 211-228.

Keaveney, Susan M. (1995), "Customer Switching Behavior in Service Industries: An Exploratory Study," Journal of Narketing, 59 (Apr i 1), 71-82.

Kelley, Scott W. and Mark A. Davis (1994). "Antecedents to Customer Expectations for Service Recovery," Journal of the Academy of Marketing Science, 22 (1), 52-61.

K. Douglas, Hoffman, and Davis, Mark A. (1993), "A Typology of Retail Failures and Recoveries," Journal of retailing, 69 (Winter), 429-452.

Krippendrof f , K. (1980), "Content Analys is," An Introduct jon to Its Methodology. Bever ly Hills: Sage Publications.

Lewis, Barbara R. and Thomas W. Entwistle (1990), "Managing the Service Encounter: A Focus on the Employee," International Journal of Service Industry Management, 1 (3), 41-52.

Meuter, Mat thew L, Amy. L, Ostrom, Robert I. Roundtree, and Mary Jo Bitner (2000),

"Self-Service Technologies Understand ing Customer Sat isf act ion wi th Technology-Based Service Encounters," Journal of Marketing, 64 (July), 50-64.

Normann. R. (1983), Service Management: Strategy and Leadership in Business. Lund, Sweden: Liber .

Parasuraman, A., Leonard L. Berry, and Valerie A. Zeithaml (1991), "Understanding Customer Expectations of Service," Sloan Management Review, 32 (3), 39-48 Valerie A. Zeithaml, and Leonard L. Berry (1985), "A Conceptual Nodel of

Service Qual ity and Its Impl icat ions for Future Research," Journal of Market ing, (Fall), 41-50.

Price, Linda L., Eric J. Arnould, and Sheila L. Deibler (1995), " Consumers' Emotional

Responses to Service Encounters: The Inf Iuence of the Service Provider, "International Journal of Service Industry Management, 6 (3), 34-63.

Ruyter Ko De, Norbert Scholl (1994), "Incident-Based Measurement of Patient

Satisfaction/Dissatisfaction: A Dutch Case," Journal of Consumer Satisfaction,

Dissatisfaction and Complaining Behavior, Vol. 7, 96-106.

Shostack, G. (1985), "Planning the Service Encounter," In the Service Encounter, John

A. Czepiel, Michael R. Solomon and Carol F. Surprenant, eds. New York: Lexington Books, 243-54.

Smith, Amy K, and Ruth No. Bolton (1998), "An Experimental Invest igation of Customer 
React ions to Service Failure and Recovery Encounters: Paradox or Peri 1?," Journal of Service Research 1(1), 65-81. and Janet Wagner (1999), "A Model of Custoner

Sat isfaction with Service Encounters Involving Failure and Recovery," Journal of Marketing Research, 34 (August), 356-372.

Stauss, Bernd (1997), "Global Word of Mouth: Bashing on the Internet is a Thorny Issue," Market ing Management, 6 (Fal1), 28-30.

(1993), "Service Problem Deployment: Transformation of problem Information intc Problem Prevent ion Act ivit ies," International Journal of Service Industry Management, $4(2), 41-62$.

Sundaram, D.S. and Cynthia Webster (2000), " The Role of Nonverbal Communicat ion in Service Encounters, " Journal of Services Marketing, 14 (5), 378-391.

Surprenant, Carol F. and Michael R. Solomon (1987), "Predictability and Personalization in the Service Encounter," Journal of Marketing, 51 (Apri1), 73-80.

Swanson, Scutt R., Scott W, Kelley (2001), "Service Recovery Attributions and Word-ofMouth Intentions," European Journal of Marketing, 35 (1), 194-211.

Tax. Stephen S. and Stephen W. Brown (1998), "Recovering and Learning for Service Failure," Sloan Management Review, 40 (1), 75-88.

- Stephen W. Brown, and Murali Chandrashekaran (1998), "Customer

Evaluations of Service Complaint Experiences: Implications for Relationship Market ing," Journal of Marketing, 62 (Apri1), 60-76.

Walker, James L. (1995), "Service Encounter Sat isfact ion: Conceptualized," Journal of Services Marketing," 9 (1), 5-23.

Weber, R.P (1985), "Basic Content Analysis," Beverly Hills: Sage Publications.

Weun, Seungoog, Sharon E. Beatty, and Michael A. Jones (forthcoming), "The Impact of Service Failure Severity on Service Recovery Evaluation and Post-Recovery Relat ionships," Journal of Services Marketing. 